\title{
Gi-DREADD Expression in Peripheral Nerves Produces Ligand-Dependent Analgesia, as well as Ligand-Independent Functional Changes in Sensory Neurons
}

\author{
- $J a m i$ L. Saloman, ${ }^{1}$ Nicole N. Scheff, ${ }^{2}$ Lindsey M. Snyder, ${ }^{1}$ Sarah E. Ross,,${ }^{1,2}$ Brian M. Davis, ${ }^{1}$ and Michael S. Gold \\ Departments of ${ }^{1}$ Neurobiology and ${ }^{2}$ Anesthesiology, University of Pittsburgh, School of Medicine, Pittsburgh, Pennsylvania 15261
}

Designer receptors exclusively activated by designer drugs (DREADDs) are an advanced experimental tool that could potentially provide a novel approach to pain management. In particular, expression of an inhibitory (Gi-coupled) DREADD in nociceptors might enable ligand-dependent analgesia. To test this possibility, TRPV1-cre mice were used to restrict expression of Gi-DREADDs to predominantly $\mathrm{C}$-fibers. Whereas baseline heat thresholds in both male and female mice expressing Gi-DREADD were normal, $1 \mathrm{mg} / \mathrm{kg}$ clozapine- $\mathrm{N}$ oxide ( $\mathrm{CNO}$ ) produced a significant $3 \mathrm{~h}$ increase in heat threshold that returned to baseline by $5 \mathrm{~h}$ after injection. Consistent with these behavioral results, $\mathrm{CNO}$ decreased action potential firing in isolated sensory neurons from Gi-DREADD mice. Unexpectedly, however, the expression of Gi-DREADD in sensory neurons caused significant changes in voltage-gated $\mathrm{Ca}^{2+}$ and $\mathrm{Na}^{+}$currents in the absence of $\mathrm{CNO}$, as well as an increase in $\mathrm{Na}^{+}$channel (NaV1.7) expression. Furthermore, $\mathrm{CNO}$-independent excitatory and inhibitory second-messenger signaling was also altered in these mice, which was associated with a decrease in the analgesic effect of endogenous inhibitory G-proteincoupled receptor activation. These results highlight the potential of this exciting technology, but also its limitations, and that it is essential to identify the underlying mechanisms for any observed behavioral phenotypes.

Key words: analgesia; DREADD; GPCR; nociception; pain; second messenger

Significance Statement

DREADD technology is a powerful tool enabling manipulation of activity and/or transmitter release from targeted cell populations. The purpose of this study was to determine whether inhibitory DREADDs in nociceptive afferents could be used to produce analgesia, and if so, how. DREADD activation produced a ligand-dependent analgesia to heat in vivo and a decrease in neuronal firing at the single-cell level. However, we observed that expression of Gi-DREADD also causes ligand-independent changes in ion channel activity and second-messenger signaling. These findings highlight both the potential and the limitations of this exciting technology as well as the necessity to identify the mechanisms underlying any observed phenotype.

\section{Introduction}

Thirty percent of the adult population suffers from chronic pain because none of the currently available therapies are consistently effective or devoid of deleterious side effects (Portenoy et al.,

Received Sept. 17, 2015; revised Aug. 2, 2016; accepted Aug. 23, 2016.

Author contributions: J.L.S., N.N.S., L.M.S., S.E.R., B.M.D., and M.S.G. designed research; J.L.S., N.N.S., L.M.S., B.M.D., and M.S.G. performed research; J.L.S., N.N.S., B.M.D., and M.S.G. contributed unpublished reagents/analytic tools; J.L.S., N.N.S., L.M.S., S.E.R., B.M.D., and M.S.G. analyzed data; J.L.S., N.N.S., S.E.R., B.M.D., and M.S.G. wrote the paper.

This work was supported by NIH Grants NS073548 (J.L.S., L.M.S.), NS086749 (J.L.S.), NS084661 (N.N.S.), NS083347 (M.S.G.), CA177857 (B.M.D.), AR063772 (S.E.R.), and AR064445 (S.E.R.).

The authors declare no competing financial interests.

Correspondence should be addressed to Brian M. Davis, E1451 Biomedical Science Tower, 200 Lothrop Street, Pittsburgh, PA 15261. E-mail: bmd1@pitt.edu.

N. N. Scheff's present address: Bluestone Center for Clinical Research, New York University, 345 E. 24th Street, Room 1038, New York, NY 10010

DOI:10.1523/JNEUROSCI.3480-15.2016

Copyright $\odot 2016$ the authors $\quad 0270-6474 / 16 / 3610769-13 \$ 15.00 / 0$
2007; Moore et al., 2010). Thus, there is a critical need for alternative approaches for the treatment of pain. Nociceptive afferent hyperexcitability is thought to underlie most chronic pain conditions, making this neuron an obvious therapeutic target. An ideal way to treat pain would therefore be to inhibit nociceptive afferents via the selective expression of an inhibitory receptor that can be activated by an exogenous compound and has no effect on endogenous binding sites or receptors. Designer receptors activated by designer drugs (DREADDs) provide a methodology to test this exciting possibility.

The Gi-DREADD, also known as human muscarinic receptor 4 (hM4Di), is a mutated muscarinic acetylcholine receptor that, when activated by its ligand, clozapine- $N$-oxide (CNO), initiates the inhibitory G-protein (Gi) signaling cascade that inhibits neuronal signaling and/or excitability. Canonically, the Gi signaling cascade is inhibitory via two major second-messenger mechanisms: (1) the Gi $\alpha$ subunit-mediated inhibition of adenylyl cy- 
clase (AC) activity (Sadana and Dessauer, 2009) that is involved in regulation of transcription factors as well as numerous protein kinase A (PKA)-regulated processes that maintain/increase neuronal excitability and (2) the direct binding of $\mathrm{Gi} \beta \gamma$ subunits to activate G-protein inwardly rectifying potassium channels (e.g., GIRKs and $K_{\text {АTP }}$ ) as well as to inhibit voltage-gated calcium channels (VGCCs; Herlitze et al., 1996; Ikeda, 1996; Ruiz-Velasco and Ikeda, 2000).

In the CNS, Gi-DREADD has been used to inhibit neuronal firing (Wess et al., 2013; Lee et al., 2014), disrupt memory consolidation when Gi-DREADD expression is targeted to ventral hippocampal glutamatergic neurons (Zhu et al., 2014), and drive schizophrenia-like behavior when targeted to parvalbumin or GAD65 interneurons (Nguyen et al., 2014). These results suggested that targeted expression of Gi-DREADD is not only feasible but enables the selective inhibition of the targeted neurons in the CNS. Recent results support the possibility that GiDREADDs could likewise be used to inhibit neurons in the PNS (Iyer et al., 2016). Thus, the goals of this study were to further explore the possibility that Gi-DREADDs are a viable tool for manipulating sensory afferents to modulate nociception and pain, as well as determine the mechanism(s) responsible for these actions.

Using behavioral, histological, and molecular biological assays and electrophysiological recordings, we show that GiDREADD activation in sensory neurons decreases excitability, thereby producing antinociception or analgesia. However, expression of Gi-DREADD under regulation of TRPV1-cre produces significant changes in voltage-gated $\mathrm{Ca}^{2+}$ and $\mathrm{Na}^{+}$ currents and disruption of both excitatory and inhibitory second-messenger signaling in the absence of CNO. Although Gi-DREADD expression in peripheral nerves does decrease excitability, unexpected ligand-independent activity may discourage use of this tool as a modulator of disease conditions, including persistent pain.

\section{Materials and Methods}

\section{Animals}

For conditional expression of Gi-DREADD in nociceptors, TRPV1-cre mice (http://jaxmice.jax.org/strain/017769.html) were crossed with mice harboring the $R C:: P D i$ allele (Ray et al., 2011), in which expression of Gi-DREADD from the Rosa locus is cre dependent. Throughout the remainder of this study, we refer to these mice as $V 1^{\text {Gi-DREADD }}$ mice. Gi-DREADD is a modified version of the hM4Di. Both male and female mice were used for all experiments. Controls were littermates lacking the TRPV1-cre allele. Animals were housed in the Association for Assessment and Accreditation of Laboratory Animal Care-accredited facility at the University of Pittsburgh in a $12 \mathrm{~h}$ light/dark cycle with a temperaturecontrolled environment and ad libitum access to water and food. Animals were cared for and studies were performed in accordance with guidelines of the Institutional Animal Care and Use Committee at the University of Pittsburgh and the National Institutes of Health Guide for the Care and Use of Laboratory Animals.

\section{Immunohistochemistry}

Animals were killed via an overdose of inhaled isoflurane and perfused transcardially with $4 \%$ paraformaldehyde (PFA). Dorsal root ganglia (DRG) were dissected, postfixed for $1 \mathrm{~h}$ in PFA, and cryoprotected in $25 \%$ sucrose in $0.1 \mathrm{M}$ phosphate buffer at $4^{\circ} \mathrm{C}$. DRG were embedded in Tissue-Tek OCT compound (Sakura Finetek), sectioned (14 $\mu \mathrm{m})$, and mounted on Superfrost Plus slides (Fisher Scientific). After several washes, sections were incubated with a HA-tag-Alexafluor 488 conjugate (1:1000; BioLegend catalog \#901509, previously Covance catalog \#A488) and IB4-Alexafluor568 conjugate (1:1000; Invitrogen) or rabbit anticalcitonin gene-related peptide (CGRP) (1:1000; Sigma). Sections were photographed using LAS software and a Leica DM 4000B microscope.
DRG neurons with distinct nuclei were counted in every fifth section (16 sections per mouse; Schmalbruch, 1987). ImageJ software (NIH) was used to measure the size profiles of 100 random neurons per animal.

\section{Behavior}

Heat. Behavioral measures were made using a plantar testing apparatus (IITC) in the University of Pittsburgh Rodent Behavior Analysis Core. Mice (control, $n=20$; Gi-DREADD, $n=19$ ) were acclimatized for $1 \mathrm{~h}$ in the thermal testing apparatus before testing. Animals were placed individually in a small Plexiglas enclosure with a glass floor. A focused light beam was applied to the plantar surface of the hindpaw. The mean of three measures of paw withdrawal latencies (PWLs) was determined at baseline and 1, 3, and $5 \mathrm{~h}$ after CNO injection ( $1 \mathrm{mg} / \mathrm{kg}$, i.p.; Sigma). A separate group of mice (control, $n=25$; Gi-DREADD, $n=25$ ) received an intraplantar injection of DAMGO or vehicle ( $5 \mu \mathrm{g} / \mathrm{paw})$ in a volume of $5 \mu \mathrm{l}$, followed by intraplantar prostaglandin $\mathrm{E}_{2}\left(\mathrm{PGE}_{2} ; 100 \mathrm{ng} / \mathrm{paw}\right)$ in a volume of $10 \mu \mathrm{l}$ (Levine and Taiwo, 1989; Taiwo and Levine, 1990; Yang and Gereau, 2002). PWL was determined at baseline and $45 \mathrm{~min}$ after $\mathrm{PGE}_{2}$.

Mechanical. Hindpaw withdrawal frequencies in response to von Frey filament stimulation were performed as described previously (Wang et al., 2013). Mice (control, $n=10$; Gi-DREADD, $n=10$ ) were acclimatized for $1 \mathrm{~h}$ before testing. Mechanical stimuli were applied from below to the plantar surface of the right hindpaw $(\sim 2-3 \mathrm{~s})$, and responses to the applied monofilament ( $\mathrm{vF} \# 3.61$, equivalent to $0.4 \mathrm{~g}$ of force) were determined. The stimulus was applied 10 times at baseline and $1 \mathrm{~h}$ after $\mathrm{CNO}$ injection ( $1 \mathrm{mg} / \mathrm{kg}$, i.p.; Sigma). The number of positive responses was converted into a percentage, with 10 positive responses corresponding to $100 \%$. The experimenter was blinded to mouse genotype for all behavioral tests.

\section{Primary DRG culture}

Mice were anesthetized with isoflurane and transcardially perfused with cold $\mathrm{Ca}^{2+} / \mathrm{Mg}^{2+}$-free HBSS (Invitrogen). Bilateral DRG (L4-L6) were dissected into cold HBSS and dissociated as described previously (Malin et al., 2007). Cells were plated in DMEM F-12 (Invitrogen) containing $10 \%$ fetal bovine serum (FBS) and antibiotics (penicillin/streptomycin, $50 \mathrm{U} / \mathrm{ml}$ ). Two hours later, coverslips were flooded with Leibovitz's L-15 medium (Invitrogen) containing 10\% FBS, $5 \mathrm{~mm}$ HEPES, and $5 \mathrm{~mm}$ glucose and stored at room temperature. Experiments were performed within $8 \mathrm{~h}$ of tissue harvest.

\section{Patch-clamp physiology}

At least three mice, including males and females, were used for all studies. Within the text, $n$ refers to the number of neurons.

Current clamp. Whole-cell patch-clamp recording were used to assess changes in the excitability of cultured DRG neurons. Borosilicate glass electrodes were filled with (in $\mathrm{mm}$ ) $110 \mathrm{~K}$-methanesulfonate, $30 \mathrm{KCl}, 5$ $\mathrm{NaCl}, 1 \mathrm{CaCl}_{2}, 2 \mathrm{MgCl}_{2}, 10 \mathrm{HEPES}, 11$ EGTA, $2 \mathrm{Mg}$-ATP, and $1 \mathrm{Li}-\mathrm{GTP}$, pH 7.2 (adjusted with Tris-base), 310 mOsm (adjusted with sucrose). Neurons were continuously superfused with a bath solution that contained (in mM) $3 \mathrm{KCl}, 130 \mathrm{NaCl}, 2.5 \mathrm{CaCl}_{2}, 0.6 \mathrm{MgCl}_{2}, 10 \mathrm{HEPES}$, and 10 glucose, pH 7.4 (adjusted with Tris-base), 325 mOsm (adjusted with sucrose). CNO-induced changes in accommodation [action potential (AP) generation] were assessed by a ramp-and-hold protocol consisting of a $250 \mathrm{~ms}$ ramp followed by $500 \mathrm{~ms}$ of sustained current injection. Accommodation was determined by counting the number of APs evoked during this protocol. The magnitude of current injection was adjusted so as to evoke an AP during the ramp phase of the stimulation protocol. This protocol was then used to stimulate neurons every $15 \mathrm{~s}$ before and after application of $10 \mu \mathrm{M} \mathrm{CNO}$, where at least three stimuli were used to establish the stability of neuronal excitability before the application of CNO. CNO was applied for $3 \mathrm{~min}$ in the majority of experiments. To facilitate comparisons between neurons, $\mathrm{CNO}$-induced changes were analyzed as a percentage change from baseline.

To begin to identify mechanisms underlying the actions of CNO, passive and active electrophysiological properties were assessed. Passive properties assessed included resting membrane potential $\left(V_{\mathrm{m}}\right)$, capacitance, and input resistance $\left(R_{\mathrm{in}}\right) . R_{\mathrm{in}}$ was estimated with the aid of amplifier circuitry before and $90-180 \mathrm{~s}$ after the application of CNO. Active 
electrophysiological properties were assessed with an AP evoked by a 4 ms depolarizing current pulse. These included the following: AP duration at $0 \mathrm{mV}$, magnitude of AP overshoot, magnitude of the afterhyperpolarization (AHP), and AHP decay ( $\tau$ AHP). The magnitude of the overshoot was measured from $0 \mathrm{mV}$. The magnitude of the AHP was measured from the $V_{\mathrm{m}}$. Decay of the AHP was estimated by fitting the decay phase of the AHP with a single exponential function.

Voltage clamp. In a subpopulation of neurons studied in current clamp, voltage-clamp data were collected before and after application of $\mathrm{CNO}$ to assess the properties of the current responsible for the inhibitory actions of CNO. Currents were evoked twice from each neuron before and after $\mathrm{CNO}$ application with the same voltage-clamp protocol: once from a holding potential of $-60 \mathrm{mV}$ and a second time from a holding potential of $-80 \mathrm{mV}$. The protocol consisted of $100 \mathrm{~ms}, 5 \mathrm{mV}$ steps from -80 to $-40 \mathrm{mV}$. To detect the presence of an increase in "leak" current, a p/4 leak subtraction protocol was not used. Series resistance compensation $(>70 \%)$ was used for all voltage-clamp recordings.

To isolate $\mathrm{Ca}^{2+}$ and $\mathrm{Na}^{+}$currents, electrodes (1-4 M $\Omega$ ) were filled with an electrode solution containing (in mM) 100 Cs-methanesulfonate, 5 Na-methanesulfonate, 40 TEA-Cl, $1 \mathrm{CaCl}_{2}, 2 \mathrm{MgCl}_{2}, 11$ EGTA, 10 HEPES, $2 \mathrm{Mg}$-ATP, and $1 \mathrm{Li}$-GTP, pH 7.2 (adjusted with Tris-base), 310 mOsm (adjusted with sucrose). The bath solution for $\mathrm{Ca}^{2+}$ current isolation contained (in mM) 100 choline-Cl, 30 TEA-Cl, $2.5 \mathrm{CaCl}_{2}, 0.6$ $\mathrm{MgCl}_{2}, 10$ HEPES, and 10 glucose, whereas the solution for $\mathrm{Na}^{+}$current isolation contained (in $\mathrm{mM}$ ) $35 \mathrm{NaCl}, 65$ choline-Cl, 30 TEA-Cl, 0.1 $\mathrm{CaCl}_{2}, 5 \mathrm{MgCl}_{2}, 10 \mathrm{HEPES}$, and 10 glucose. Both bath solutions were $\mathrm{pH}$ 7.4 (adjusted with Tris-base), and osmolarity was adjusted to $325 \mathrm{mOsm}$ with sucrose. Voltage-gated $\mathrm{Na}^{+}$currents (VGSCs) were evoked from a holding potential of $-60 \mathrm{mV}$. To isolate the slowly inactivating tetrodotoxin (TTX)-resistant $\mathrm{Na}^{+}$current (TTX-R $I_{\mathrm{Na}}$ ) from the more rapidly activating and inactivating TTX-sensitive $\mathrm{Na}^{+}$currents (TTX-S $I_{\mathrm{Na}}$ ), a steady-state inactivation protocol was used to determine the conditioning step amplitude needed for full availability of TTX-S $I_{\mathrm{Na}}$ as well as the potential at which TTX-S $I_{\mathrm{Na}}$ was completely inactivated. These two potentials were then used as $500 \mathrm{~ms}$ conditioning steps before the collection of current-voltage $(I-V)$ data, which consisted of $15 \mathrm{~ms}$ voltage steps from -50 to $+30 \mathrm{mV}$ in $5 \mathrm{mV}$ increments (with a $5 \mathrm{~s}$ interstep interval). TTX-S $I_{\mathrm{Na}}$ was separated from the total current by digitally subtracting the TTX-R $I_{\mathrm{Na}}$ from the total current. $\mathrm{Na}^{+}$current conductance-voltage $(G-V)$ data were estimated from $I-V$ data based on the measured reversal potential. Voltage-gated $\mathrm{Ca}^{2+}$ currents were evoked from a holding potential of $-60 \mathrm{mV}$. I-V data were generated with $50 \mathrm{~ms}$ voltage steps from -70 to $+45 \mathrm{mV}$ in $5 \mathrm{mV}$ steps. $\mathrm{Ca}^{2+}$ current $G-V$ data were measured directly from the instantaneous $I-V$ associated with tail currents evoked during the collection of $I-V$ data. To minimize the impact of leak currents on isolation of voltage-gated $\mathrm{Na}^{+}$and $\mathrm{Ca}^{2+}$ currents, a $-\mathrm{p} / 4$ protocol was used for $\mathrm{Na}^{+}$currents, with a holding potential of $-70 \mathrm{mV}$ during the acquisition of the leak pulses, whereas a $\mathrm{p} / 4$ protocol was used for $\mathrm{Ca}^{2+}$ currents with a holding potential of -90 $\mathrm{mV}$ during the acquisition of the leak pulses. $G-V$ data were fitted with a Boltzmann equation to estimate the maximal conductance $\left(G_{\max }\right)$ and the potential at which half-maximal conductance was activated $\left(V_{1 / 2}\right)$. To monitor drug effects and stability of evoked current, peak inward current was evoked at $0 \mathrm{mV}$ every $5 \mathrm{~s}$. Finally, a prepulse potentiation protocol was used to monitor the extent to which inhibition of $\mathrm{Ca}^{2+}$ currents was $\mathrm{G} \beta \gamma$ dependent. A neuron was considered responsive to a drug if the peak current was changed by $10 \%$ of baseline.

\section{Drugs}

CNO (Sigma) was dissolved in DMSO to a stock concentration (100 mM) and then further diluted in sterile saline $(1 \mathrm{mg} / \mathrm{kg}$, behavior) or recording buffer (10 $\mu \mathrm{M}$, electrophysiology). DAMGO (Tocris) was dissolved in water to a stock concentration of $1 \mathrm{~mm}$ and then further diluted in recording buffer $(1 \mu \mathrm{M}$, electrophysiology) or sterile saline $(1 \mu \mathrm{g} / \mu \mathrm{l}, 5 \mu \mathrm{l}$, i.pl., behavior). $\mathrm{PGE}_{2}$ (Sigma) was dissolved to a stock concentration of $10 \mathrm{mg} / \mathrm{ml}$ in ethanol and then further diluted to a working concentration of $10 \mathrm{nl} / \mu \mathrm{l}$ in sterile saline. Forskolin (10 and $30 \mu \mathrm{M}$; Tocris) was dissolved to a stock concentration of $20 \mathrm{~mm}$ in DMSO and then further diluted to the working concentration in recording buffer.
Table 1. PCR primers

\begin{tabular}{|c|c|c|}
\hline Gene & Accession number & Primer \\
\hline KCNJ3 (GIRK1, Kir3.1) & D45022 (PrimerBank) & $\begin{array}{l}\text { Forward: GGGGACGATTACCAGGTAGTG } \\
\text { Reverse: CGCTGCCGTTTCTTCTTGG }\end{array}$ \\
\hline KCNJ6 (GIRK2, Kir3.2) & NC_000082.6 & $\begin{array}{l}\text { Forward: CGATGGAAGACGGGTTCTACGAAG } \\
\text { Reverse: TTCAGTTTGCTGGACCAAC }\end{array}$ \\
\hline KCNJ9 (GIRK3, Kir3.3) & U11860 (PrimerBank) & $\begin{array}{l}\text { Forward: AAGGACGGTCGCTGTAACG } \\
\text { Reverse: CGAGCACGAAGAAGAGCAGT }\end{array}$ \\
\hline KCNJ5 (GIRK4, Kir3.4) & U33631 (PrimerBank) & $\begin{array}{l}\text { Forward: GCCGGTGATTCTAGGAATGCT } \\
\text { Reverse: TCCTGAACATTACCGTGGTGT }\end{array}$ \\
\hline SCN9A (Nav1.7) & NM_018852.2 & $\begin{array}{l}\text { Forward: CCTTGGCCCCATTAAATCTCT } \\
\text { Reverse: TGCTCCTATGAGTGCGTTGAC }\end{array}$ \\
\hline SCN10A (Nav1.8) & NM_009134.2 & $\begin{array}{l}\text { Forward: TTGACACAACCTCGCTCTATTCC } \\
\text { Reverse: ATTTCACCCTGGGTCTTCTCTCA }\end{array}$ \\
\hline CACNA1A (Cav2.1) & NC_000074.6 & $\begin{array}{l}\text { Forward: TCTCTGGGCCGATACACTGA } \\
\text { Reverse: CGGAACTACTGCCCTGTCTG }\end{array}$ \\
\hline CACNA1B (Cav2.2) & NC_000068.7 & $\begin{array}{l}\text { Forward: ATCCGCATCCTATTGTGGACC } \\
\text { Reverse: GTCATCATCAAGGGCACTGTTTC }\end{array}$ \\
\hline 0prm1 ( $\mu$ receptor) & NC_000076.6 & $\begin{array}{l}\text { Forward: GCCCTCTACTCTATCGTGTGTGTA } \\
\text { Reverse: GTTCCCATCAGGTAGTTGACACTC }\end{array}$ \\
\hline Oprd1 ( $\delta$ receptor) & NC_000070.6 & $\begin{array}{l}\text { Forward: GGAAGCAGAGCTGGTGATTCCT } \\
\text { Reverse: TCCTGGTCCCTGGAGCTGGAAT }\end{array}$ \\
\hline Oprk1 ( $\kappa$ receptor) & NC_000067.6 & $\begin{array}{l}\text { Forward: GGTGGGCTTAGTGGGCAAT } \\
\text { Reverse: GACAGCACTCTGGAAGGGCA }\end{array}$ \\
\hline CHRM4 (hmAChR4) & NM_000741.3 & $\begin{array}{l}\text { Forward: GGGTACTGTCCTTCGTGCTC } \\
\text { Reverse: GTGGATGTACAGCACCGTCA }\end{array}$ \\
\hline GAPDH & NC_000072.6 & $\begin{array}{l}\text { Forward: ATGTGTCCGTCGTCGTGGATCTGA } \\
\text { Reverse: ATGCCTGCTTCACCACCTTCTT }\end{array}$ \\
\hline
\end{tabular}

Shown is a list of primers used to assess effects of Gi-DREADD expression on endogenous GPCR transcription.

\section{$q P C R$}

DRG RNA was isolated from seven to nine mice per group using the RNeasy mini kit (Qiagen). RNA $(0.5 \mu \mathrm{g})$ was treated with DNase (Invitrogen) to remove genomic DNA and reverse-transcribed using Superscript II reverse transcriptase (Invitrogen). Real-time PCR was used as described previously to determine the extent of expression of various channels and receptors in DREADD-expressing sensory neurons compared with control littermates (Malin et al., 2006). Primers were designed using Oligo software (Molecular Biology Insights) and the Harvard PrimerBank (Wang et al., 2012). Primer sequences used are listed in Table 1. SYBR Green PCR amplification was performed using a Bio-Rad CFX connect real-time system. After amplification, a dissociation curve was plotted against the melting temperature to ensure amplification of a single product. All samples were run in duplicate, and as a negative control, reactions were run with the reverse transcribed control reaction products but without template. The relative fluorescence of SYBR Green bound to double-stranded DNA was compared with a passive reference for each cycle. Threshold cycle $(\mathrm{Ct})$ values, the cycle number in which SYBR Green fluorescence rises above background, were recorded as a measure of initial template concentration. Relative fold changes in RNA levels were calculated by the $\Delta \Delta \mathrm{Ct}$ method using GAPDH as a reference standard: Ct values from duplicate samples were averaged and subtracted from the reference standard, yielding $\Delta \mathrm{Ct}$. The difference between the $\Delta \mathrm{Ct}$ of target genes from experimental and control groups were then calculated $(\Delta \Delta \mathrm{Ct})$. Relative expression was determined as $2^{-\Delta \Delta \mathrm{Ct}}$.

\section{Statistical analysis}

Student's $t$ test was used to compare two groups, whereas statistical analyses for differences over time in multiple groups were performed on GraphPad Prism software using two-way repeated-measures ANOVA followed by the Holm-Sidak post hoc test. Data from males and females were pooled unless, as where indicated, significant sex differences were detected. Data are presented as the mean \pm SEM. For all analyses, significance was set at $p<0.05$.

\section{Results}

\section{Peripheral expression of Gi-DREADDs}

To investigate the utility of Gi-DREADDs for the inhibition of nociception, Gi-DREADDs were expressed in C-fibers using the 

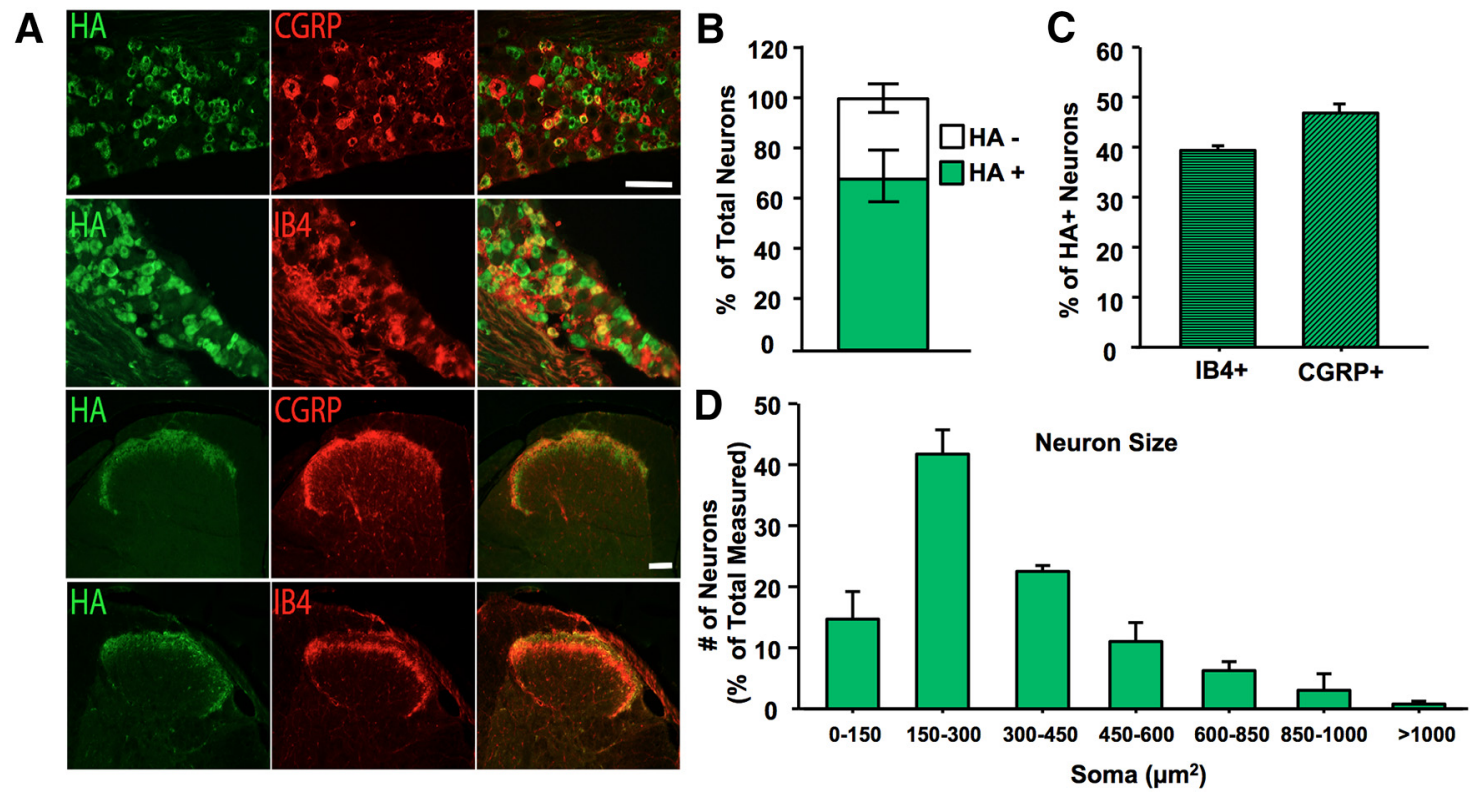

Figure 1. HA-tagged Gi-DREADD expression in L4 DRG. $A$, Gi-DREADD expression was confirmed by staining with an HA-488-conjugated antibody. Scale bars, $100 \mu \mathrm{m}$. $\boldsymbol{B}$, The majority (67 \pm 1.7\%) of neurons in L4 DRG express the HA-tag for Gi-DREADD (solid green bar, HA+). C, Gi-DREADD is expressed in predominantly IB4- and CGRP-positive neurons. D, Gi-DREADD is expressed in predominantly small $\left(150-300 \mu \mathrm{m}^{2}\right)$ neurons. $n=4$.
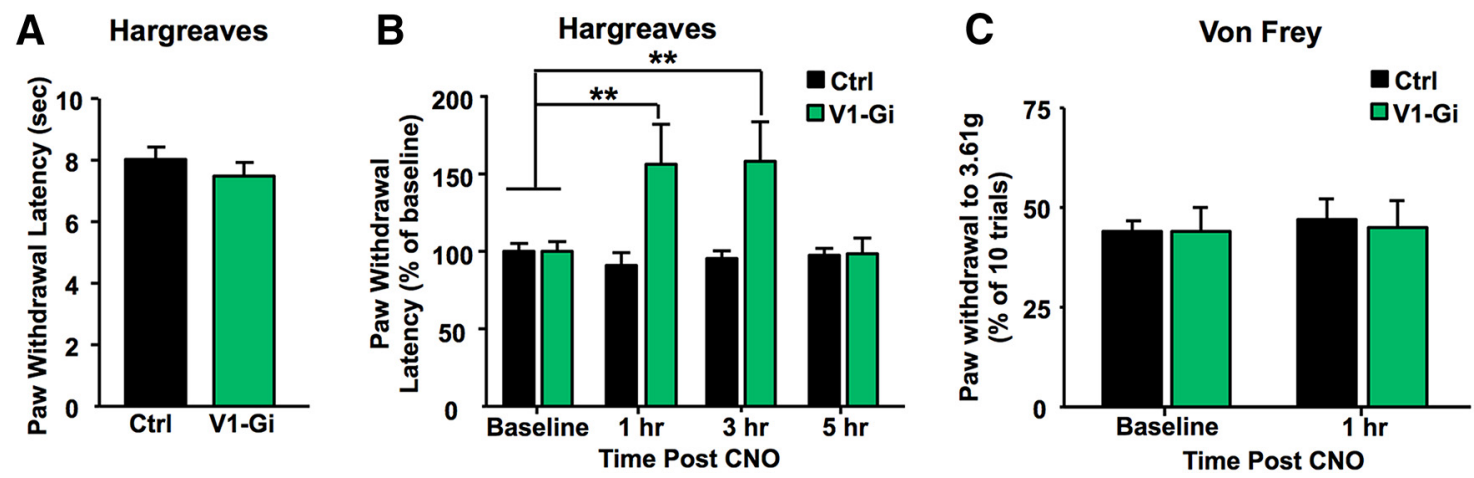

Figure 2. The effect of CNO activation on thermal and mechanical sensitivity. $A$, Raw data showing no significant difference in baseline thermal sensitivity between control (black) and $V\}^{G i-D R E A D D}$ (green) mice. B, CNO (1 mg/kg, i.p.) significantly increased thermal thresholds for $3 \mathrm{~h}$ after injection. C, CNO (1 mg/kg, i.p.) had no detectable influence on mechanical sensitivity. Changes were assessed with a two-way repeated-measures ANOVA; $n=9-10$ per group, ${ }^{* *} p<0.01$. Ctrl, Control.

TRPV1-cre allele (see Materials and Methods) combined with a cre-responsive Gi-DREADD effector allele (Ray et al., 2011). We subsequently refer to these mice as $V 1^{G i-D R E A D D}$ mice. Because the expression of TRPV1 is broader during embryonic development than in the adult (Cavanaugh et al., 2011), TRPV1-cre results in recombination in the majority of C-fibers. To confirm successful recombination and Gi-DREADD expression, we used an anti-HA-488-conjugated antibody to locate Gi-DREADDexpressing cells in the DRG and spinal cord (Fig. 1A). No cell bodies were labeled within the spinal cord, but a band of immunoreactivity in lamina I/II of the dorsal horn was observed, consistent with Gi-DREADD expression in primary afferent terminals (Fig. 1A). In L4 DRG, $67 \pm 1.7 \%$ of neurons expressed Gi-DREADD compared with the total absence of HA immunoreactivity in control littermates (Fig. $1 B$ ). Greater than $87 \%$ of Gi-DREADD-expressing neurons are IB4 or CGRP positive, $39 \pm 0.9 \%$ and $47 \pm 1.8 \%$, respectively (Fig. $1 C$ ). Moreover, $84 \pm$ $2.1 \%$ of IB4-positive neurons and $80 \pm 2.0 \%$ of CGRP-positive neurons express Gi-DREADD, all with small to medium-sized $\left(\leq 450 \mu \mathrm{m}^{2}\right)$ somata. Furthermore, HA immunoreactivity was present in predominantly small neurons (Fig. $1 D$ ), suggesting that TRPV1-cre was successful in restricting expression of GiDREADD to C-fibers and a small population of putative A- $\delta$ nociceptors.

Activation of Gi-DREADDs induces heat analgesia but has no effect on mechanical sensitivity

To determine the effect of activated inhibitory DREADDs on heat thresholds, $V 1^{G i-D R E A D D}$ mice and control littermates were tested using the Hargreaves' assay for heat sensitivity. Baseline PWL was similar in both $V 1^{G i-D R E A D D}$ and control mice (Fig. $2 A$ ). However, $1 \mathrm{~h}$ after CNO injection $\left(1 \mathrm{mg} / \mathrm{kg}\right.$, i.p.), $V 1^{\text {Gi-DREADD }}$ mice exhibited a significant increase in PWL lasting for $3 \mathrm{~h}$ (Fig. $2 B$; $F_{(3,51)}=5.537, n=9-10$ per group, $\left.p<0.01\right)$. In a separate group of animals, the same dose of CNO had no effect on mechanical thresholds $\left(F_{(1,18)}=0.12, n=10\right.$ per group, $p=0.74$; Fig. $2 C$ ). The mice tested for changes in mechanical sensitivity were tested for thermal sensitivity on two different occasions to confirm the efficacy and activity of CNO. Similar to the cohort shown in Figure $2 A$, these $V 1^{G i-D R E A D D}$ mice also exhibited a 
A

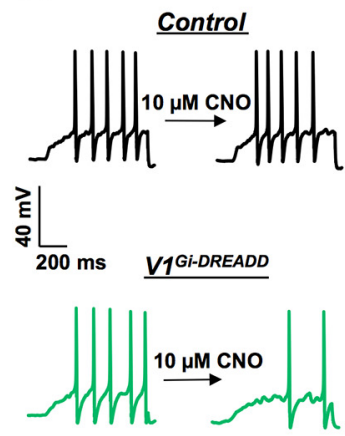

B

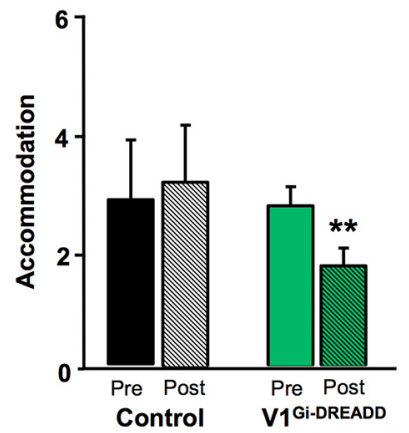

C

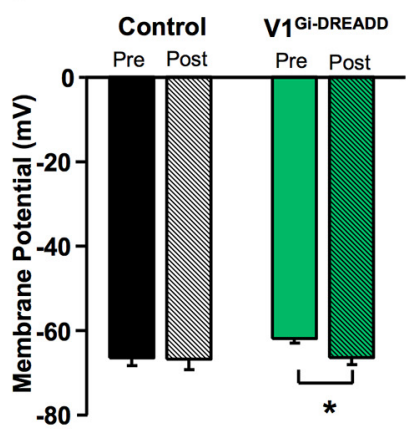

D

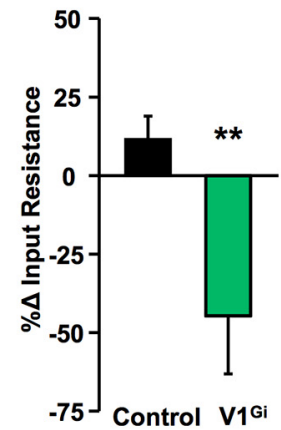

Figure 3. Impact of CNO on neuronal excitability. A ramp-and-hold protocol consisting of a $250 \mathrm{~ms}$ ramp followed by a $500 \mathrm{~ms}$ sustained current injection was used to assess accommodation. $A$, APs evoked during the ramp-and-hold protocol from representative DRG neurons from $V 1^{\text {Gi-DREADD }}$ (green trace) and littermate control (black trace) mice before and after CNO application. $\boldsymbol{B}$, Pooled data show a significant decrease in accommodation after $10 \mu \mathrm{m}$ CNO (striped) in neurons from V1 ${ }^{G i-D R E A D D}$ mice (green, $\left.n=22\right)$ compared with littermate controls (black, $n=6$ ). $C, D, C N 0$ also resulted in a significant decrease in membrane potential $(\boldsymbol{C})$ and input resistance $(\boldsymbol{D})$ in the same populations plotted as a percentage change from baseline. Statistical analysis was assessed for all measures using a two-way ANOVA with Holm-Sidak post hoc analysis where ${ }^{*} p<0.05,{ }^{* *} p<0.01$.

significant increase in PWL to radiant heat $\left(F_{(1,12)}=14.10, n=\right.$ 10 per group, $p<0.01)$. These data demonstrate that a systemic dose of $1 \mathrm{mg} / \mathrm{kg} \mathrm{CNO}$ produces heat, but not mechanical analgesia, and that CNO can be given multiple times and still produce a comparable degree of analgesia.

\section{CNO-Gi-DREADD signaling reduces neuronal excitability and modulates AP shape}

To identify the mechanism(s) underlying the actions of $\mathrm{CNO}$ in the $V 1^{G i-D R E A D D}$ mice, whole-cell current-clamp experiments were performed on dissociated DRG (L4-L6) neurons from $V 1^{G i-D R E A D D}$ and littermate control mice to measure the effect of $\mathrm{CNO}$ on primary afferent excitability. In neurons from $V 1^{\text {Gi-DREADD }}$ mice, application of CNO $(10 \mu \mathrm{M})$ resulted in a significant decrease in accommodation (Fig. $3 A, B$ ), a hyperpolarization of the membrane potential (Fig. $3 C$ ), and a decrease in input resistance $\left(R_{\text {in }}\right.$; Fig. $\left.3 D\right)$. There was no significant difference between neurons from male and female mice with respect to the proportion of neurons in which CNO reduced excitability, nor was there a difference in the magnitude of the decrease in excitability (data not shown; Fisher's exact test, $p=0.09$ ).

The active electrophysiological parameters, as defined in Figure $4 A$, were compared between neurons from control and $V 1^{\text {Gi-DREADD }}$ mice (Table 2). CNO had no effect on any parameter measured in neurons from littermate controls but induced a significant decrease in AP duration and AHP magnitude in neurons from $V 1^{G i-D R E A D D}$ mice. Interestingly, however, even in the absence of $\mathrm{CNO}$, there were significant differences between groups with respect to active electrophysiological properties. The AP overshoot was significantly smaller and AP duration was longer in neurons from the $V 1^{G i-D R E A D D}$ mice compared with neurons from control mice, suggesting that expression of Gi-DREADD, in the absence of ligand, is sufficient to alter channel properties within sensory neurons.

Although the CNO-induced changes in active electrophysiological properties suggested that activation of the voltage-gated $\mathrm{K}^{+}$channel(s) may contribute to the decrease in excitability, the changes in passive electrophysiological properties were consistent with a CNO-induced activation of a GIRK channel. We therefore sought to determine whether any of the GIRK isoforms were present in mouse DRG. Consistent with the literature (Nockemann et al., 2013), GIRK1-3 are expressed in brain and spinal cord, with GIRK4 mRNA found only in the spinal cord
(Fig. 4B). In contrast, GIRK1 and GIRK2 mRNA were detected in both control and Gi-DREADD-expressing mouse DRG. There were no significant differences in GIRK1/2 expression between genotypes (Fig. 4B). Interestingly, however, there was a significant effect of sex on GIRK2 expression in controls, but not $V 1^{\text {Gi-DREADD }}$ mice, with females $(n=5)$ expressing lower levels of GIRK2 $\left(F_{(1,10)}=9.411, p=0.012\right.$; data not shown $)$ compared with control males $(n=4)$.

Consistent with the change in AP duration and because changes in passive properties may have also reflected the activation of a low-threshold voltage-gated (LVA) $\mathrm{K}^{+}$current, we performed a preliminary analysis of the $\mathrm{CNO}$-induced changes in $\mathrm{K}^{+}$currents in a subpopulation of neurons from $V 1^{\text {Gi-DREADD }}$ mice. A low-threshold current was present in every neuron studied $(n=15)$. The currents recorded were outwardly rectifying (Fig. $4 C$, inset) and potentiated over 12 -fold with membrane hyperpolarization: from $1.5 \pm 0.1 \mathrm{pA} / \mathrm{pF}$ peak outward current at $-40 \mathrm{mV}$ evoked from a holding potential of $-60 \mathrm{mV}$ to $26 \pm 6.3$ $\mathrm{pA} / \mathrm{pF}$ when current was evoked from a holding potential of -80 $\mathrm{mV}$. Interestingly, in neurons in which $\mathrm{CNO}$ was associated with a decrease in excitability $(n=6)$, there was a significant increase in low-threshold outward current (Fig. 4C). This increase in outward current was not associated with a significant increase in inwardly rectifying current, at least at $-80 \mathrm{mV}$. There was no detectable change in current in neurons unresponsive to $\mathrm{CNO}$ $(n=9$; Fig. $4 D)$.

\section{Gi-DREADD expression suppresses AC signaling and} voltage-gated $\mathrm{Na}^{+}$currents in the absence of $\mathrm{CNO}$

The smaller AP overshoot in DRG neurons from $V 1^{\text {Gi-DREADD }}$ mice in the absence of CNO suggested that there was a constitutive suppression of VGSCs in these neurons. To directly assess this possibility, we recorded VGSCs in isolated sensory neurons from $V 1^{G i-D R E A D D}$ and control mice in voltage clamp (Fig. $5 A$ ). First, we focused on the TTX-R $I_{\mathrm{Na}}$ because it has been shown to be the dominant, if not the only, VGSC to underlie the upstroke of the action potential in putative nociceptive DRG neurons (England et al., 1996). Although there was no difference between groups with respect to half-maximal voltage ( $V_{1 / 2}$; Table 3; unpaired Student's $t$ test, $p=0.129)$, maximal conductance $\left(G_{\max }\right)$ was significantly smaller in neurons from $V 1^{\text {Gi-DREADD }}$ mice (11.5 $\pm 2.2 \mathrm{pS} / \mathrm{pF}, n=15)$ compared with neurons from control littermates (20.2 $\pm 3.9 \mathrm{pS} / \mathrm{pF}, n=10$; Fig. $5 B$; unpaired Student's 
A

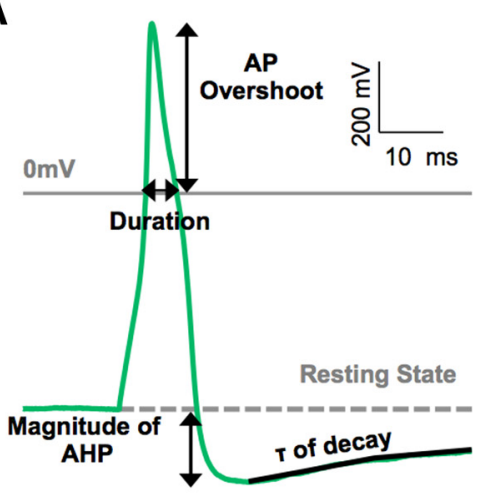

B

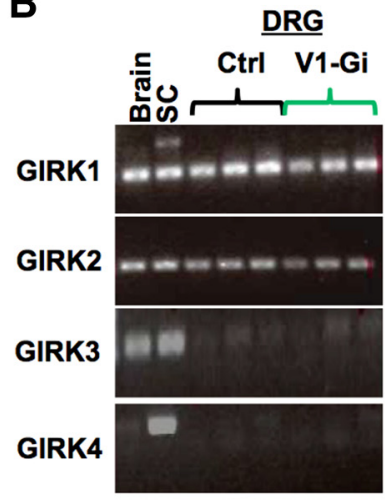

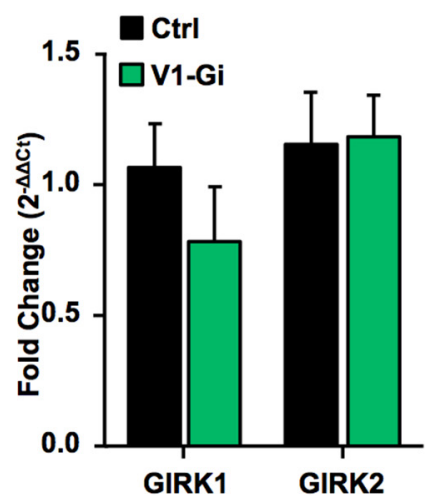

C
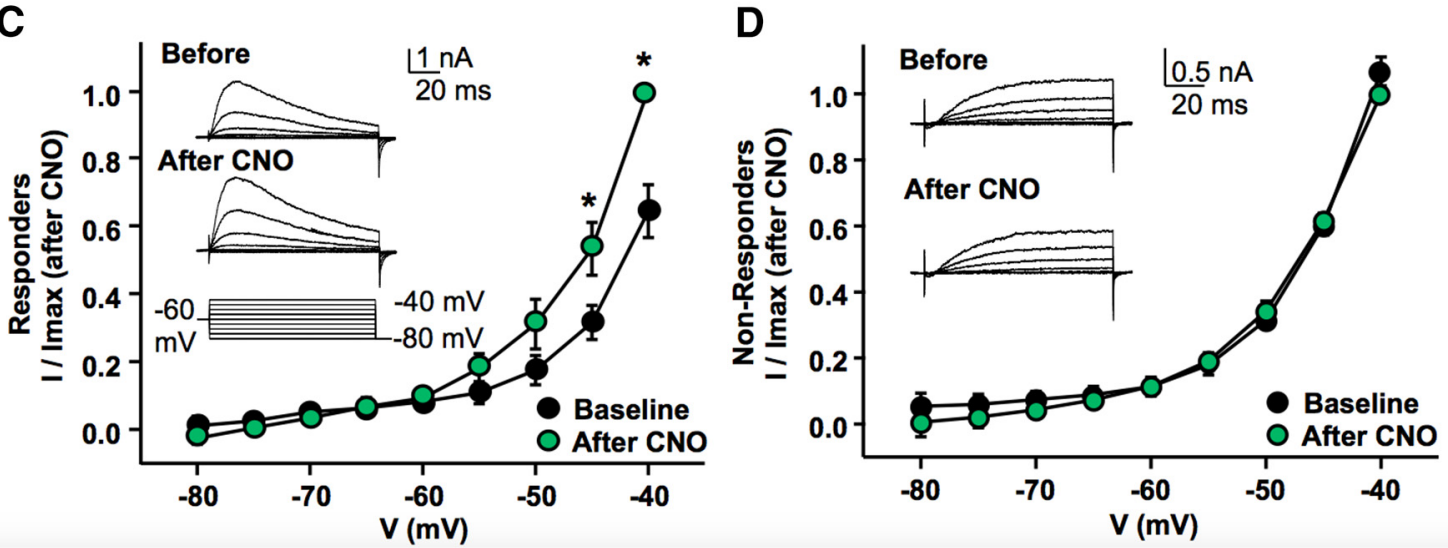

Figure 4. Potassium current changes underlying CNO-induced inhibition. $A$, A representative AP from a neuron from a $V 1^{G i-D R E A D D}$ mouse in which we defined the active electrophysiological properties analyzed. $\tau$ is the time constant of decay. $\boldsymbol{B}$, Left, GIRK1 and GIRK2, but not GIRK3 and GIRK4, mRNA are expressed in mouse DRG. Right, Pooled data show that there is no significant difference in GIRK1/2 expression between DRG from V1 ${ }^{\text {Gi-DREADD }}$ mice (green, $n=7-9$ per group) and littermate controls (Ctrl; black, $n=7-9$ per group); $\mathrm{mRNA}$ expression changes were assessed with a two-way ANOVA. SC, Spinal cord. C, A population of neurons demonstrating suppression in spike number in response to CNO ( $n=6$ ) also displayed a significant increase in voltage-gated K ${ }^{+}$ currents (VGKCs) with step depolarization to -45 and $-40 \mathrm{mV}$ in response to CNO application. $D$, In neurons in which there was no effect of CNO in current clamp ( $n=9$ ), no change in VGKC was detected. There was no difference in the baseline current density between CNO responders (1.53 $\pm 0.2 \mathrm{pA} / \mathrm{pF})$ and nonresponders (1.47 $\pm 0.2 \mathrm{pA} / \mathrm{pF})$ at $50 \mathrm{mV}$. However, after $\mathrm{CNO}$, the differences are significant at $-50,-45$, and $-40 \mathrm{mV}$ (two-way repeated-measures ANOVA, ${ }^{*} p<0.05$ ).

Table 2. CNO-induced changes in active electrophysiological properties in neurons from $V 1^{G i-D R E A D}$ mice $(n=15)$ and littermate controls $(n=10)$

\begin{tabular}{|c|c|c|c|c|}
\hline & \multicolumn{2}{|l|}{ Control } & \multicolumn{2}{|l|}{ V1 ${ }^{\text {Gi-DREADD }}$} \\
\hline & Before CNO & After CNO & Before CNO & After CNO \\
\hline AP overshoot $(\mathrm{mV})^{\#}$ & $51.4 \pm 1.3$ & $51.3 \pm 0.6$ & $42.3 \pm 6.0$ & $41.2 \pm 4.3$ \\
\hline Duration $(\mathrm{ms})^{¥}$ & $4.7 \pm 0.3$ & $4.8 \pm 0.3$ & $6.4 \pm 1.2$ & $4.6 \pm 0.6^{* *}$ \\
\hline $\operatorname{AHP}(m V)^{¥ ¥}$ & $-12.9 \pm 2.4$ & $-13.9 \pm 1.7$ & $-18.3 \pm 1.4$ & $-11.2 \pm 1.4^{* *}$ \\
\hline AHP decay $(t, m s)$ & $241.1 \pm 73.4$ & $174.2 \pm 55.1$ & $106.1 \pm 11.4$ & $126.6 \pm 23.1$ \\
\hline
\end{tabular}

A single $4 \mathrm{~ms}$ depolarizing current injection was used to measure CNO-induced changes in active properties as defined in Fig. 4A. Two-way ANOVA with Holm-Sidak post hoc analysis assessed active properties. ${ }^{*} p<0.05$, main effect of genotype; ${ }^{*} p<0.05$, interaction between genotype and CNO treatment; ${ }^{* ¥} p<0.01$, interaction between genotype and $\mathrm{CNO}$ treatment. ${ }^{* *} p<0.01$, post hoc comparison of $\mathrm{CNO}$ treatment within genotype.

$t$ test, $p=0.043)$. To rule out the possible influence of cell-body size on the $G_{\max }$, all cells were normalized by membrane capacitance. The smaller $G_{\max }$ in $V 1^{G i-D R E A D D}$ mice did not appear to be attributable to a change in channel expression in the $V 1^{\text {Gi-DREADD }}$ mice as there was no significant influence of genotype on Nav1.8 mRNA levels (Fig. 5C). Analysis of TTX-R $I_{\mathrm{Na}}$ by sex and genotype (two-way ANOVA) revealed a significant influence of genotype (lower peak current density and $G_{\max }$ in neurons from $V 1^{\text {Gi-DREADD }}$ compared with controls) and sex (lower peak current density and $G_{\max }$ in females compared with males) but no significant interaction. Although Nav1.9 has also been implicated in the control of nociceptive afferent excitability and shown to be modulated by G-protein-coupled receptor (GPCR) signaling (Maruyama et al., 2004; Rush and Waxman, 2004; Ostman et al., 2008; Vanoye et al., 2013), the activation of this current is so slow that it makes little direct contribution to the upstroke of the action potential (and would not have been detectable in the $15 \mathrm{~ms}$ voltage steps used to study $\mathrm{Na}^{+}$currents in these neurons). Additionally, whereas a CNO-induced decrease in a persistent $\mathrm{Na}^{+}$ current could have contributed to the membrane potential hyperpolarization as well as the decrease in excitability observed, such a change should have been associated with an increase in membrane resistance. Because a decrease in membrane resistance was observed, the possibility of changes in Nav1.9-mediated currents was not pursued further.

Although originally included as a control for potential changes in Nav1.8 expression, we detected a significant influence of genotype on Nav1.7 expression in DRG, with $V 1^{\text {Gi-DREADD }}$ mice expressing significantly more Nav1.7 (Fig. 5C; Student's $t$ test, $p=0.031 ; n=7-8$ per group). Nav1.7 is the TTX-sensitive $\alpha$ subunit thought to underlie the majority of TTX-S $I_{\mathrm{Na}}$ in putative nociceptive neurons (Zhang et al., 2013). To determine whether this increase in expression was associated with an increase in TTX-S $I_{\mathrm{Na}}$, a voltage-clamp protocol was used to isolate TTX-S currents for direct study (Gold et al., 1996a). Consistent with the PCR data, the TTX-S current density (Fig. 5D) was significantly larger in neurons from $V 1^{G i-D R E A D D}$ mice $(-26.7 \pm 6.0$ 

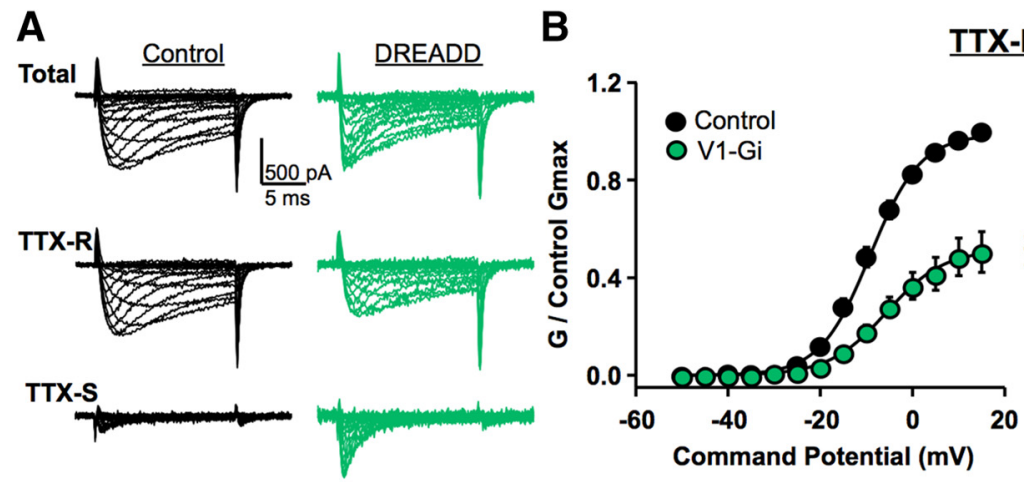

ITX-R I-Na

C
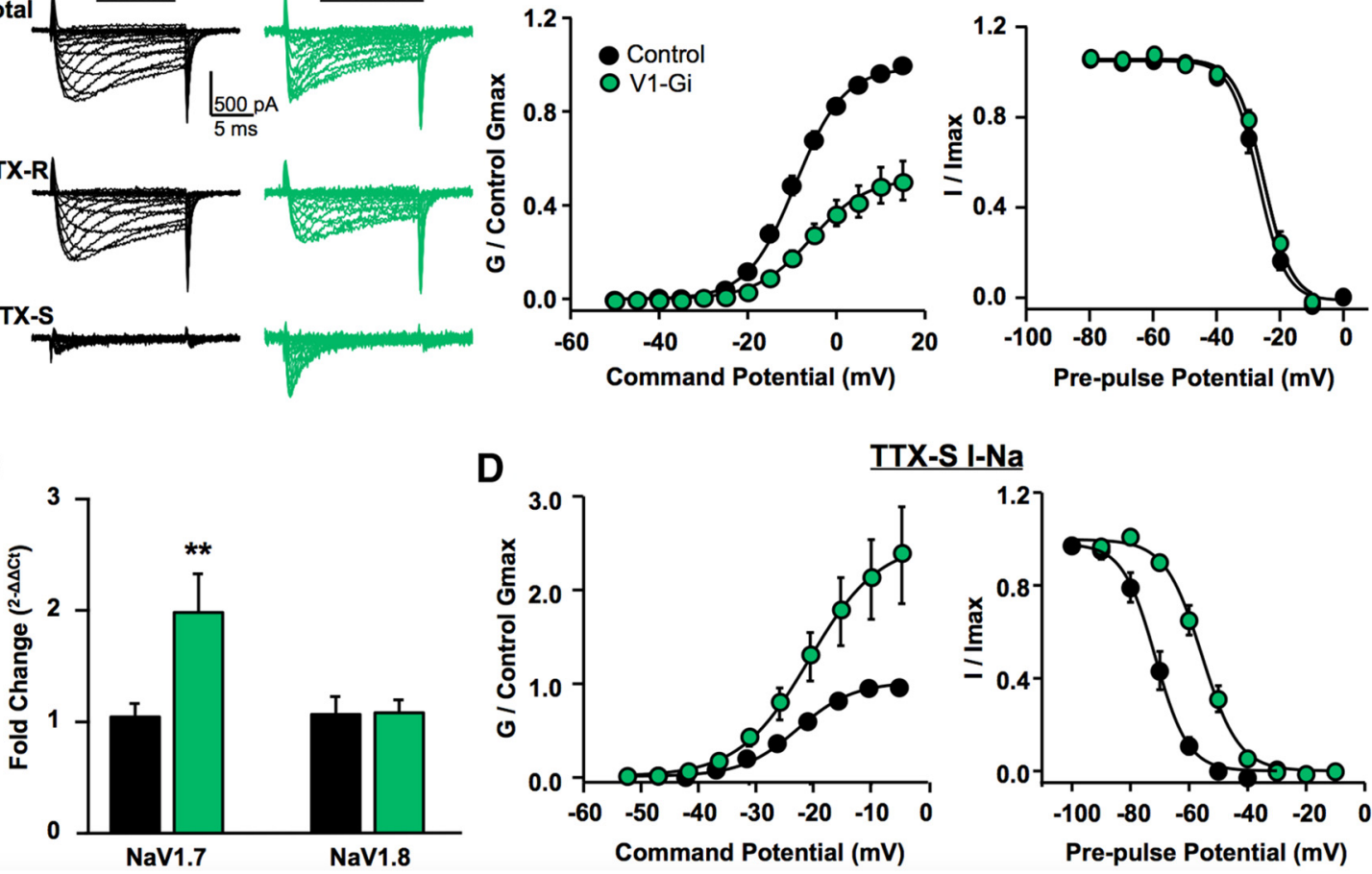

ITX-S I-Na

Figure 5. Voltage-gated $\mathrm{Na}^{+}$currents in control versus $V 1^{G i-D R E A D D}$ neurons. $A$, Representative traces from current-voltage protocol from $V 1^{G i-D R E A D D}$ mouse (green) and littermate control (black) for total $\mathrm{Na}^{+}$current (top), TTX-R (middle), and TTX-S (bottom) currents. B, Pooled TTX-R Na ${ }^{+}$conductance-voltage data from V1 $1^{G i-D R E A D D}$ (green, $n=20$ ) and littermate control (black, $n=$ 19) mice showing a significant suppression of $\mathrm{Na}^{+}$maximal conductance $\left(G^{\mathrm{max}}\right)$ but no change in half-maximal conductance $\left(V_{1 / 2}\right)$. C, This decrease in maximal conductance is not attributable to a change in voltage-dependent $\mathrm{Na}^{+}$channel 1.8 expression $(n=7-9)$, but there is a significant increase in Nav1.7 $(n=7-9)$. D, Pooled TTX-S Na ${ }^{+}$conductance-voltage data from V $7^{G i-D R E A D D}$ (green, $n=9$ ) and littermate control (black, $n=8$ ) mice showing a significant increase in TTX-S Na ${ }^{+}$maximal conductance $\left(G_{\text {max }}\right)$ and a depolarizing shift in prepulse potential. To highlight changes in $G_{\max }, V 1^{G i-D R E A D D}$ neurons were normalized to the average $G_{\max }$ of controls.

Table 3. Biophysical properties of TTX-R and TTX-S Na ${ }^{+}$currents in neurons from $V 1^{\text {Gi-DREAD }}$ mice $(n=15)$ and littermate controls $(n=10)$

\begin{tabular}{|c|c|c|c|c|}
\hline & \multicolumn{2}{|l|}{ Inactivation } & \multicolumn{2}{|l|}{ Activation } \\
\hline & $V_{1 / 2}(\mathrm{mV})$ & Slope & $V_{1 / 2}(\mathrm{mV})$ & Slope \\
\hline \multicolumn{5}{|l|}{ TTX-R } \\
\hline Control & $-26.8 \pm 1.4$ & $3.8 \pm 0.2$ & $-9.2 \pm 1.0$ & $5.3 \pm 0.2$ \\
\hline$V 1^{G i-D R E A D D}$ & $-24.9 \pm 0.9$ & $3.9 \pm 0.2$ & $-8.8 \pm 1.2$ & $5.6 \pm 0.2$ \\
\hline \multicolumn{5}{|l|}{ TTX-S } \\
\hline Control & $-72.1 \pm 2.6$ & $5.2 \pm 0.3$ & $-22.2 \pm 0.3$ & $5.2 \pm 0.6$ \\
\hline$V 1^{G i-D R E A D D}$ & $-55.8 \pm 1.7^{* *}$ & $5.9 \pm 0.3$ & $-19.6 \pm 1.0^{*}$ & $5.9 \pm 0.3$ \\
\hline
\end{tabular}

Conductance-voltage data were fitted with a Boltzmann equation to estimate the potential at which half-maximal conductance was activated $\left(V_{1 / 2}\right)$ and sloped. Student's $t$ test was used to assess differences in current properties.

${ }^{*}$ Indicates a significant difference between $V 1{ }^{G i-D R E A D D}$ and littermate controls where ${ }^{*} p<0.05,{ }^{* *} p<0.01$.

$\mathrm{pA} / \mathrm{pF}, n=8)$ than that in neurons from control littermates $(-12.8 \pm 2.2 \mathrm{pA} / \mathrm{pF}, n=9)$. Furthermore, there were differences in the biophysical properties of the TTX-S currents in these two groups of neurons. The $V_{1 / 2}$ of current inactivation was significantly more depolarized in neurons from $V 1^{G i-D R E A D D}$ mice than that in littermate controls, as was the $V_{1 / 2}$ of current activation (Table 3).

Finally, given evidence that activation of PKA can increase TTX-R $I_{\mathrm{Na}}$ in putative nociceptive DRG neurons (England et al., 1996; Gold et al., 1998) via direct phosphorylation of Nav1.8 (Fitzgerald et al., 1999), the decrease in current density in neurons from $V 1^{G i-D R E A D D}$ mice suggested that there may be constitutive suppression of AC in these neurons. To test this prediction, we used the AC activator forskolin $(10 \mu \mathrm{M})$ to attempt to normalize TTX-R $I_{\mathrm{Na}}$ currents in Gi-DREADD neurons (Fig. 6A), as well as confirm that $\mathrm{CNO}$-induced activation of Gi-DREADD was capable of blocking the forskolin-induced increase in TTX-R $I_{\mathrm{Na}}$. In control neurons, forskolin $(10 \mu \mathrm{M})$ increased peak TTX-R $I_{\mathrm{Na}}$ by $32.1 \pm 7.7 \%(n=31$; Fig. $6 B)$. However, in neurons from $V 1^{\text {Gi-DREADD }}$ mice before CNO treatment, there was no effect of forskolin on any neuron tested, suggesting that AC activation of TTX-R $I_{\mathrm{Na}}$ currents was blocked by constitutive action(s) of the Gi-DREADD $(n=27$; Fig. $6 B)$. Furthermore, not surprisingly, CNO application to $V 1^{\text {Gi-DREADD }}$ neurons caused no further suppression of TTX-R $I_{\mathrm{Na}}$ (Fig. $6 C$ ). Finally, to rule out a potential "floor effect" of a constitutive suppression of $\mathrm{AC}$, we assessed the impact of a higher concentration of forskolin $(30 \mu \mathrm{M})$ on TTX-R $I_{\mathrm{Na}}$ in three neurons from $V 1^{G i-D R E A D D}$ mice. As with $10 \mu \mathrm{M}$ forskolin, $30 \mu \mathrm{M}$ forskolin resulted in no detectable $(-2.2 \%)$ changes in peak TTX-R $I_{\mathrm{Na}}$.

Gi-DREADD expression was associated with constitutive ligand-independent suppression of $\mathrm{Ca}^{2+}$ currents

Whereas activation of inwardly rectifying $\mathrm{K}^{+}\left(K_{\mathrm{IR}}\right)$ currents appears to be a common mechanism of inhibitory GPCR signaling in CNS neurons and there is evidence that $K_{\mathrm{IR}}$ currents are present in nociceptive afferents (Gao et al., 2007; Kawano et al., 2009), there is little direct evidence of $\mathrm{Gi}-K_{\mathrm{IR}}$ signaling in rodent DRG neurons (McCleskey, 2000). Instead, inhibition of VGCCs (McCleskey, 2000) and AC (Taiwo and Levine, 1991) appears to be the primary mechanisms responsible for the actions of inhibitory GPCR activation. Therefore, evidence of CNO-induced activation of a $\mathrm{K}^{+}$current in our current and voltage-clamp experiments was unexpected and raised the possibility that GiDREADD expression may have altered normal Gi signaling in these neurons. To test this possibility, we first sought to deter- 
A
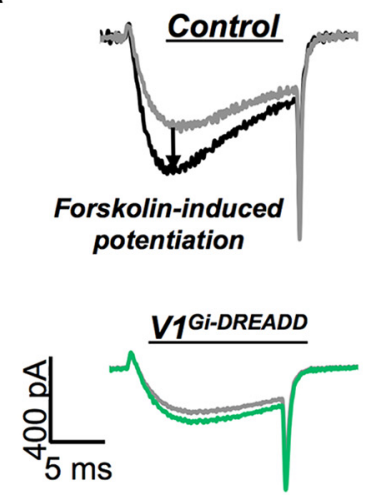

B

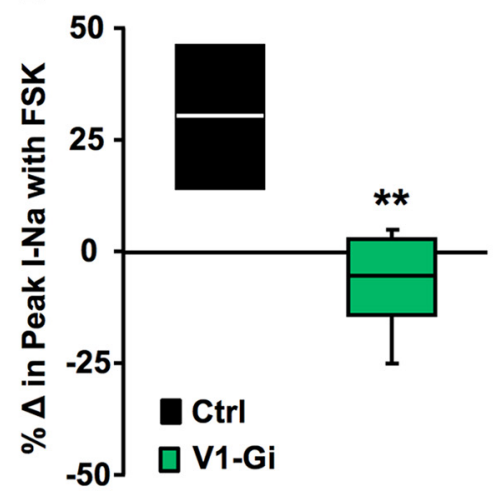

C

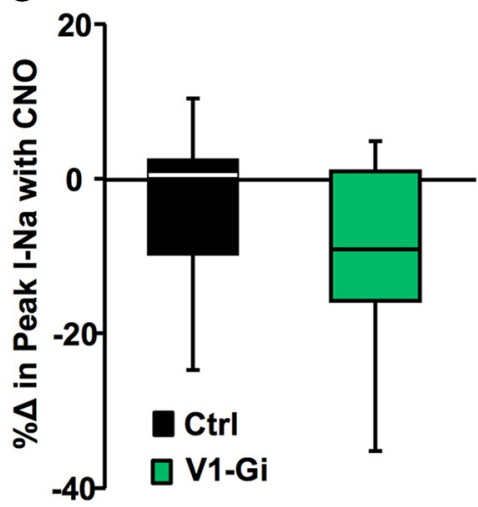

Figure 6. $A$, Representative trace of peak inward current evoked at $0 \mathrm{mV}$ before (black) and after (black, control; green, $V 1^{G i-D R E A D D}$ ) application of $10 \mu \mathrm{m}$ forskolin. $\boldsymbol{B}, \boldsymbol{C}$, Pooled impact of forskolin (FSK; $\boldsymbol{B}, 10 \mu \mathrm{M})$ and CNO (C, $10 \mu \mathrm{M}$ ) on peak Na ${ }^{+}$current evoked from neurons from control (black, $n=9$ ) and $V 1^{G i-D R E A D D}$ (green, $n=11$ ) mice. These data were analyzed as percentage change from baseline using a box and whisker plot attributable to the wide distribution of data. Physiology statistics were determined using a two-way ANOVA with Holm-Sidak post hoc test or Student's t test. ${ }^{* *} p<0.01$. Ctrl, Control.

mine whether activation of Gi-DREADD resulted in the suppression of VGCCs, as has been described for all other inhibitory GPCRs present in sensory neurons (Altier and Zamponi, 2008; Ditting et al., 2012). Tail currents were used to generate instantaneous $G-V$ curves evoked before and after application of $\mathrm{CNO}$ or the $\mu$-opioid receptor (MOR) agonist DAMGO $(1 \mu \mathrm{M})$.

Analysis of baseline $G-V$ data indicated that even before the application of $\mathrm{CNO}$, VGCCs were smaller in neurons from $V 1^{G i-D R E A D D}$ mice compared with neurons from control littermates (Fig. 7A, B; two-way ANOVA with Holm-Sidac post hoc test). The decrease in VGCC conductance was not associated with a detectable decrease in expression of VGCC $\alpha$ subunits underlying N-type (CaV2.2) or P/Q-type (CaV2.1) channels (Fig. 7B, inset), which account for the majority of high-threshold current in sensory neurons (Bourinet et al., 2014). Additionally, analysis of $G_{\max }$ by sex and genotype (two-way ANOVA) revealed a significant influence of both as well as a significant interaction. Post hoc analysis shows significantly lower $G_{\max }$ in female mice compared with male mice $(t=3.06, p<0.01)$ and in $V 1^{G i-D R E A D D}$ females compared with control females $(t=3.69, p<0.01)$. There was no shift in the $V_{1 / 2}$ of channel activation in neurons from control and $V 1^{G i-D R E A D D}$ mice $(-4 \pm 1.1$ and $-6 \pm 1.2 \mathrm{mV}$, respectively; $p>0.05$, unpaired $t$ test). There was also no difference in the voltage dependence of activation in neurons from control and $V 1^{G i-D R E A D D}(7.7 \pm 0.2$ and $8.0 \pm 0.4 \mathrm{mV} / \mathrm{e}$-fold, respectively; $p>0.05$, unpaired $t$ test). This absence of significant shifts argues against the possibility that the decrease in VGCC conductance was caused by constitutive suppression of channel activity via the G-protein $\beta \gamma$ subunit. Nevertheless, we performed two additional analyses to further rule out this possibility. First, we analyzed the rate of current activation at $0 \mathrm{mV}$, because channels in the "sleepy" or "unwilling" state attributable to the actions of the G $\beta \gamma$ subunit activate more slowly (Ikeda, 1996). Consistent with the $G-V$ data, there was no significant influence of genotype on the rate of VGCC current activation (Fig. 7C). Second, because $\mathrm{G} \beta \gamma$-mediated modulation of channel gating can be relieved with a depolarizing prepulse (to $+80 \mathrm{mV}$ ) (Ikeda, 1996), we used a two-pulse protocol to determine whether it was possible to normalize current density in $V 1^{\text {Gi-DREADD }}$ mice. The increase in current evoked at $0 \mathrm{mV}$ after a prepulse to $+80 \mathrm{mV}$ was calculated as a percentage of the current evoked at $0 \mathrm{mV}$ from a holding potential of $-70 \mathrm{mV}$. Although there was a trend to- ward a larger prepulse potentiation in neurons from $V 1^{\text {Gi-DREADD }}$ mice $(22 \pm 3 \%, n=11$ compared with $14 \pm 2 \%, n=16)$, this difference was not significant $(p=0.06$; Fig. $7 D)$.

\section{Gi-DREADD disrupts endogenous inhibitory GPCR} expression and second-messenger coupling

Despite the constitutive suppression of VGCCs in putative nociceptive DRG neurons from $V 1^{\text {Gi-DREADD }}$ mice, the $\mathrm{CNO}$-induced decrease in AP duration was also consistent with a further CNOinduced decrease in VGCC current, which could also contribute to the analgesic effects observed. Therefore, we next assessed the impact of CNO on VGCCs. For comparison, we also assessed the impact of endogenous $\mathrm{Gi}$ activation with the MOR agonist DAMGO. Two voltage-clamp protocols were used. The first was a voltage step to $0 \mathrm{mV}$ every $5 \mathrm{~s}$. Whereas the time course of current suppression could not be reasonably assessed with such a low stimulation rate, it still enabled distinguishing relatively fast signaling, which was complete within two steps or $10 \mathrm{~s}$, as well as relatively slow signaling developing over tens of seconds. The second was the two-pulse protocol used to assess the extent of G $\beta \gamma$-mediated suppression of VGCCs (Ikeda, 1996). The results of this analysis indicated that $\mathrm{CNO}$ application had no detectable influence on peak inward VGCC current, with what appeared to be a time-dependent decrease in current in neurons from both control and $V 1^{\text {Gi-DREADD }}$ mice (Fig. $8 A$ ). Even more striking, DAMGO-induced suppression of VGCCs in neurons from $V 1^{\text {Gi-DREADD }}$ mice in the absence of CNO was significantly attenuated compared with control mice (Fig. 8A). Furthermore, the fractional recovery of current with a prepulse in neurons from $V 1^{G i-D R E A D D}$ mice was significantly smaller than that in neurons from control littermates (Fig. $8 B$ ). The application of CNO produced no further changes in this parameter (data not shown).

Given the finding that expression of Gi-DREADD alters the cellular properties in DRG neurons, we wondered whether this change in phenotype was attributable to expression of GiDREADD at nonphysiological levels. To address this possibility, we measured mRNA levels of muscarinic type 4 receptors (CHRM4) by qPCR with primers that detect both mouse M4 and ectopic human M4Di receptors (i.e., the Gi-DREADD). As expected, CHRM4 levels were elevated $(\sim 13$-fold $)$ in $V 1^{\text {Gi-DREADD }}$ mice relative to control littermates (presumably, attributable in large part to Gi-DREADD expression). Importantly, however, 
A

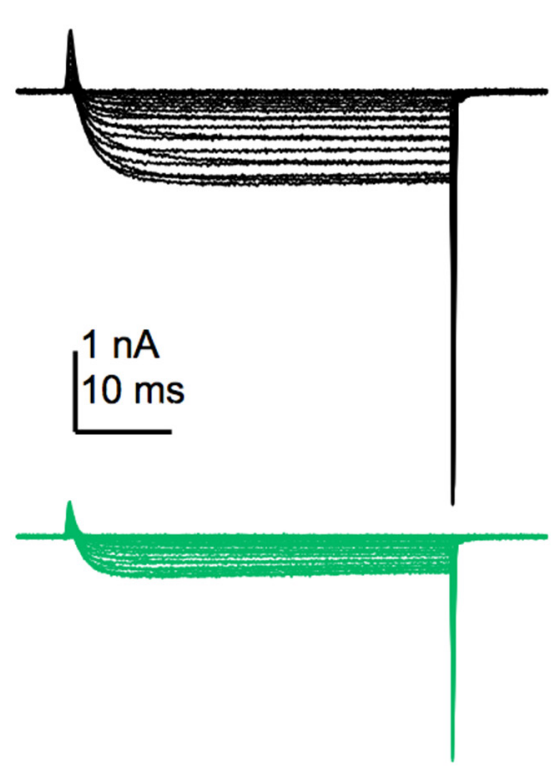

C

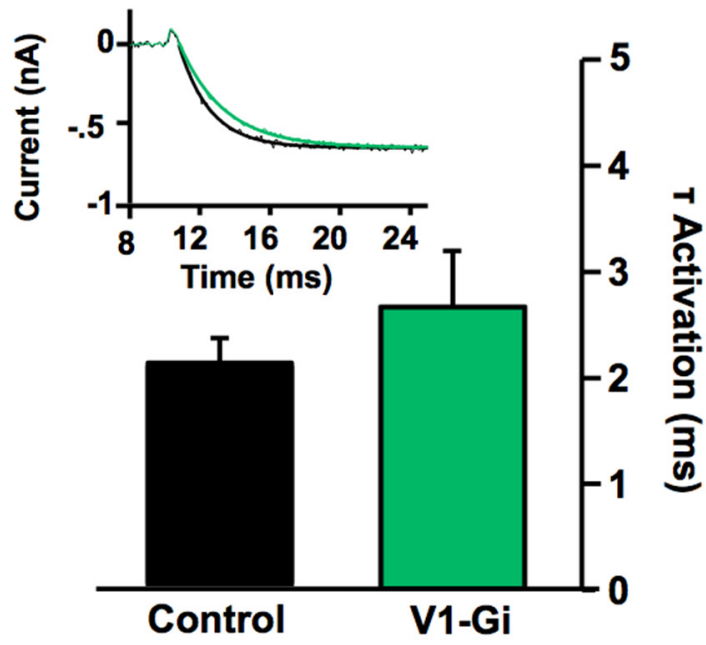

B

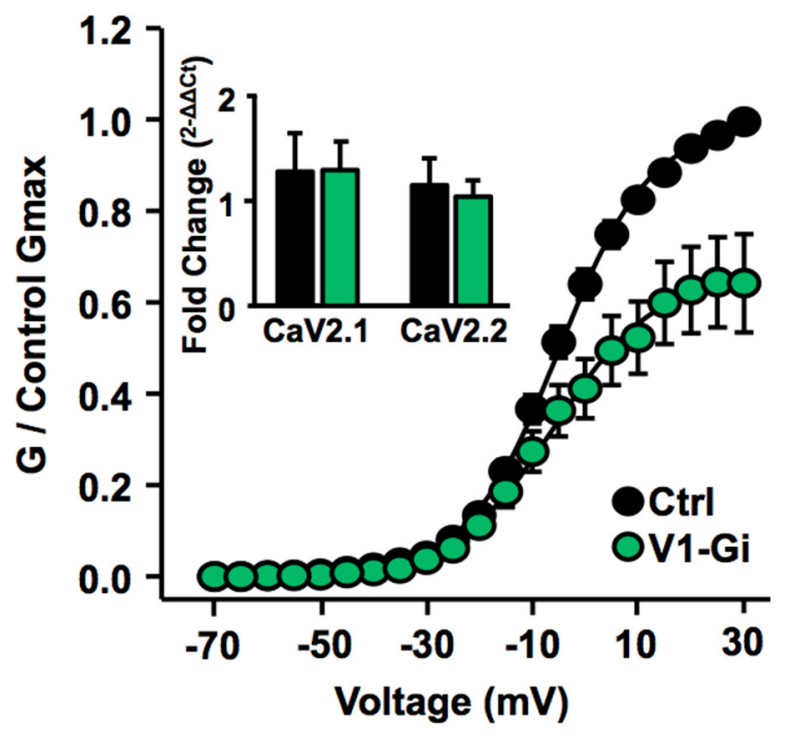

D

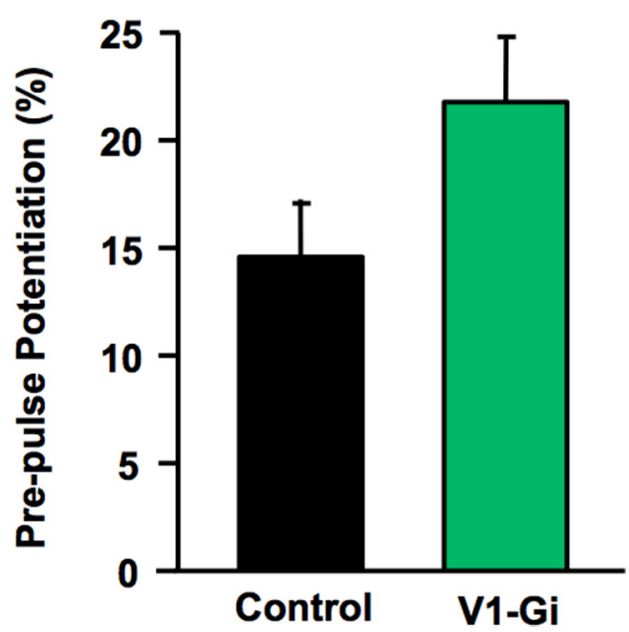

Figure 7. Voltage-gated $\mathrm{Ca}^{2+}$ currents in control versus $V 1^{G i-D R E A D D}$ neurons. $A$, Representative traces from $\mathrm{Ca}^{2+}$ current-voltage protocol from $V 1^{G-D R E A D D}$ mouse (green) and littermate control (black) mice. B, Pooled conductance-voltage data from V $1^{G i-D R E A D D}$ (green, $n=18$ ) and littermate control (Ctrl; black, $n=18$ ) mice showing a significant suppression of $C^{2}{ }^{2+}$ conductance (two-way ANOVA revealed significant interaction between voltage and genotype, $F=7.685, p<0.01)$, no change in half-maximal conductance $\left(V_{1 / 2}\right)$, and no significant effect of genotype on Cav2.1 or Cav2.2 expression (inset; $n=7-9$ per group; two-way ANOVA, $p>0.05$ ). C, There was no difference (Student's $t$ test, $p>0.05$ ) in the time constant $(\tau)$ of activation in neurons from $V 7^{G i-D R E A D D}$ mice (green, $n=12$ ) compared with controls (black, $n=14$ ). Inset, Current activation is more rapid in control neurons (black trace) compared with that in $V 1^{G i-D R E A D D}$ neurons (green trace). D, Pooled data show the increase in the inward current evoked after a prepulse to $+80 \mathrm{mV}$ was increased in neurons from $V 1^{G i-D R E A D D}$ mice (green, $n=11$ ) compared with controls (black, $n=16$ ); however, this was not significantly different (Student's $t$ test, $p>0.05$ ).

levels of CHRM4 in $V 1^{\text {Gi-DREADD }}$ mice were comparable with that of the MOR (Ct values of $24.08 \pm 0.5$ and $23.51 \pm 0.4$, respectively), suggesting that although expression of Gi-DREADD was sufficient to drive both behavioral and cellular responses, expression of the receptor would have been in a physiological range even if all of the CHMR4 mRNA recovered from $V 1^{G i-D R E A D D}$ mice was human rather than a combination of human and mouse receptors. Furthermore, expression of Gi-DREADD had no detectable influence on expression levels of other inhibitory G-protein-coupled receptors in DRG including, $\mu$ (MOR), $\delta$ (DOR), and $\kappa(\mathrm{KOR})$ (Fig. $9 A, B$ ). It is also worth noting that relative levels of MOR, DOR, KOR, and CHRM4 in control mice were comparable with those recently described in an RNASeq-based analysis of expression levels in DRG (Goswami et al., 2014).
To assess the functional consequences of the apparent changes in endogenous Gi signaling in putative nociceptive neurons, we assessed the ability of DAMGO to prevent $\mathrm{PGE}_{2}$-induced thermal hypersensitivity. Intraplantar $\mathrm{PGE}_{2}(100 \mathrm{ng})$ significantly reduced PWL to $54.3 \pm 3.7 \%(n=8)$ and $73.2 \pm 12.3 \%(n=7)$ of baseline in controls and $V 1^{\text {Gi-DREADD }}$ mice, respectively. This response to $\mathrm{PGE}_{2}$ was associated with neither a significant influence of genotype or sex $\left(F_{(1,21)}=0.13, p=0.73\right)$ nor a significant interaction between the two. The response to DAMGO was more complicated as there were significant main effects of both sex and genotype (sex: $F_{(1,21)}=12.35, p=0.002$; genotype: $F_{(1,21)}=$ $6.233, p=0.021$; Fig. $9 C)$. $\mathrm{PGE}_{2}$-induced hyperalgesia was significantly attenuated in control $(n=8)$ but not $V 1^{\text {Gi-DREADD }}(n=8)$ male mice. In contrast, DAMGO had no detectable effect in female mice regardless of genotype. 
A

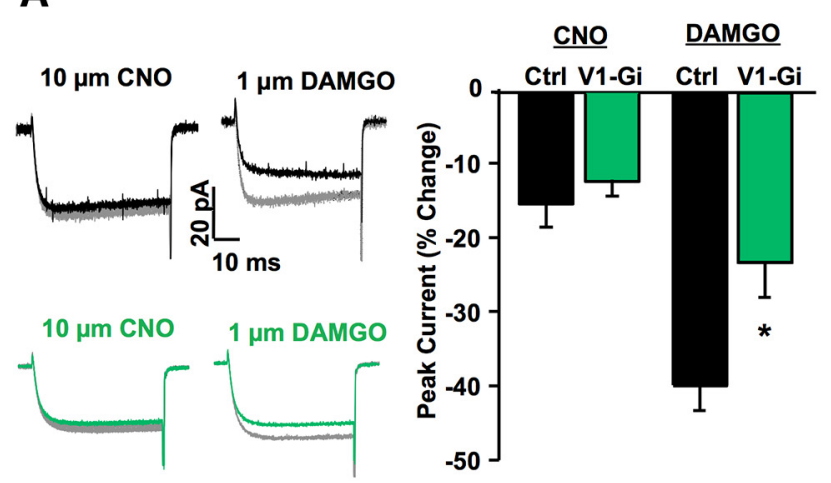

B

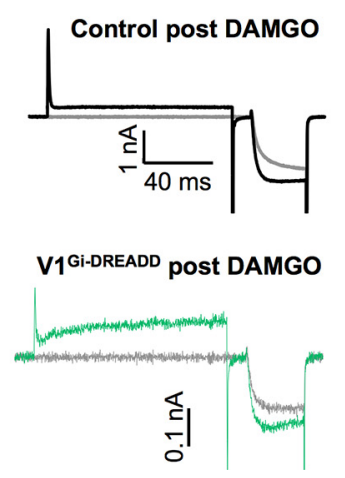

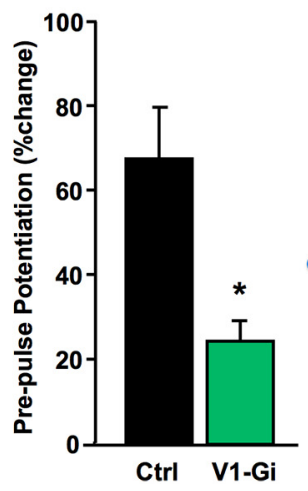

Figure 8. Effect of Gi-DREADD expression on modulation of $\mathrm{Ca}^{2+}$ signaling. $\boldsymbol{A}$, Left, Peak inward current evoked at $0 \mathrm{mV}$ before (gray) and after (black, control; green, $V 7^{G i-D R E A D D}$ ) $\mathrm{CNO}$. Middle, $\mathrm{Ca}^{2+}$ current evoked before (gray) and after (black, control; green, $\left.V 1^{G i-D R E A D D}\right) 1 \mu \mathrm{m}$ DAMG0. Right, Pooled data analyzed as percentage change from baseline for each neuron studied demonstrate no significant effect of CNO from control (black, $n=19)$ and $V 1$ Gi-DREADD (green, $n=19$ ) mice. However, application of $1 \mu \mathrm{m}$ DAMGO resulted in significantly less suppression of Ca ${ }^{2+}$ current in $V 1^{G i-D R E A D D}$ (green, $n=10$ ) compared with control (black, $n=13$ ) mice. Data were analyzed as percentage change from baseline for each neuron studied. $\boldsymbol{B}$, Left, Representative $C a^{2+}$ current prepulse traces before (black) and after (black, control; green, $\left.V 1^{G i-D R E A D D}\right) 1 \mu \mathrm{M}$ DAMGO from neurons studied from both genotypes. Right, Pooled data show the increase in the inward current evoked after a prepulse to $+80 \mathrm{mV}$ was significantly attenuated in neurons from V1 ${ }^{G i-D R E A D D}$ mice $(n=10)$ after DAMGO application compared with controls (Ctrl; $\left.n=13\right)$. Data were analyzed by Student's $t$ test as a percentage change of the current evoked from $-70 \mathrm{mV} ;{ }^{*} p<05$.
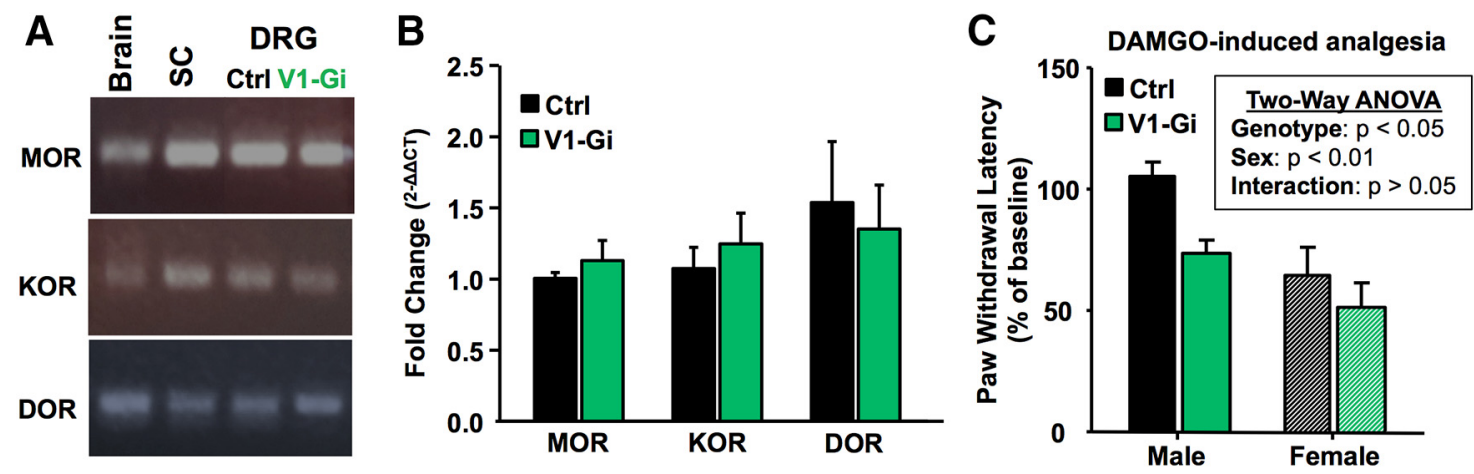

Figure 9. Effect of Gi-DREADD expression on endogenous Gi-coupled GPCRs. $A$, Example gel demonstrating Gi-coupled opioid receptors MOR, DOR, and KOR expressed in both $V 7^{G i-D R E A D D}$ (Gi) and littermate control (Ctrl) DRG. SC, Spinal cord. B, There is no significant difference ( $p>0.05$ ) between genotypes in the expression of MOR, KOR, or DOR (green, V1 ${ }^{G i-D R E A D D}$; black, control). Data are pooled across sexes because no significant effect of sex was detected ( $p>0.05$ ). The calibration gene is GAPDH. Gene expression was assessed by a two-way ANOVA ( $n=9$ per group). $C$, Pooled data assessing DAMG0-induced attenuation of thermal hypersensitivity evoked by a single intraplantar injection of $100 \mathrm{ng}$ of $P G E_{2}$. Data are presented as a percentage change from baseline response in both male (solid bars) and female (striped bars) $V 1^{G i-D R E A D D}$ (green) and littermate control (black) mice. Two-way ANOVA reveals a significant effect of genotype $(p<0.05)$ and sex ( $p<0.01$ ) but no significant interaction.

\section{Discussion}

Based on the efficacy of DREADD technology in the CNS, we predicted that targeted expression of Gi-DREADD in nociceptive afferents would enable CNO-induced analgesia. Although there was no detectable impact of Gi-DREADD expression on baseline heat or mechanical thresholds, $\mathrm{CNO}$ application resulted in heat analgesia in $V 1^{G i-D R E A D D}$ mice. Furthermore, in isolated DRG neurons from $V 1^{G i-D R E A D D}$ mice, $C N O$ decreased AP firing. The decrease in excitability was associated with a decrease in $R_{\text {in }}$, hyperpolarization of the resting membrane potential and activation of a low-threshold $\mathrm{K}^{+}$channel. CNO had no detectable influence on VGCCs in sensory neurons from $V 1^{G i-D R E A D D}$ mice. However, we observed baseline differences ( $\mathrm{CNO}$ independent) in ion channel properties in neurons from $V 1^{\text {Gi-DREADD }}$ mice compared with littermate controls. Specifically, there was a significant decrease in maximal TTX-R $I_{\mathrm{Na}}$, an increase in TTX-S $I_{\mathrm{Na}}$, and a decrease in VGCC conductance. There was also a loss of forskolin-induced potentiation of TTX-R $I_{\mathrm{Na}}$ and a decrease in the magnitude of the DAMGO-induced inhibition of VGCCs. In vivo, the loss of DAMGO effect was also detected, as DAMGO failed to block $\mathrm{PGE}_{2}$-induced hyperalgesia in $V 1^{\text {Gi-DREADD }}$ mice.
Together, these data suggest that although it is possible to manipulate behavior via ligand-mediated Gi-DREADD activity, constitutive expression of this receptor has unintended consequences that complicate interpretation of the results.

Consistent with recent data using an AAV-based strategy to drive Gi-DREADD expression in sensory neurons (Iyer et al., 2016), initial behavioral results with the $V 1^{G i-D R E A D D}$ mice were quite promising. Given that the receptor should have no activity in the absence of $\mathrm{CNO}$, we anticipated that baseline thermal and mechanical thresholds would be normal. Since pharmacological or toxin-induced ablation of TRPV1 signaling selectively renders animals unresponsive to noxious heat (Cavanaugh et al., 2009; Mishra and Hoon, 2010; Mishra et al., 2011), we predicted that silencing the TRPV1 population with CNO-induced activation of Gi-DREADDs would also result in an attenuation of the response to noxious heat, but not mechanical, stimuli. A wider pattern of expression associated with AAV-driven Gi-DREADD may explain the presence of both mechanical and thermal analgesia reported previously (Iyer et al., 2016).

Previous data indicate that peripheral administration of endogenous Gi-coupled receptor agonists does not produce 
analgesia (Levine and Taiwo, 1989; Stein, 1993) but rather attenuates hyperalgesia produced by Gs-coupled receptors via inhibition of AC (Dina et al., 2005), as might occur after injury or inflammation. In contrast, spinal administration of agonists for Gi-coupled receptors is analgesic via what is thought to be inhibition of presynaptic VGCCs (Heinke et al., 2011). Thus, we anticipated that the analgesia associated with systemic administration of $\mathrm{CNO}$ would reflect an action at the central terminals of TRPV1cre-expressing neurons.

Unexpectedly, CNO attenuated the excitability of isolated DRG neurons. A more likely outcome was an increase in excitability caused by a decrease in large-conductance $\mathrm{Ca}^{2+}$ dependent $\mathrm{K}^{+}$(BK) channel activity caused by CNO-induced inhibition of VGCCs (Zhang et al., 2012). Given their role in membrane potential repolarization during the falling phase of the AP (Zhang et al., 2010), a decrease in BK current would result in an increase in excitability and AP duration. The absence of a CNO-induced decrease in VGCCs may explain why there was no evidence of a secondary change in excitability or active electrophysiological properties that are dependent on BK channels. However, a reduced BK current associated with the observed CNO-independent reduction in VGCCs could account for the longer AP duration observed in neurons from $V 1^{\text {Gi-DREADD }}$ mice.

More surprisingly was that the response to $\mathrm{CNO}$ included a decrease in $R_{\text {in }}$ in combination with a hyperpolarization of resting membrane potential, at least in neurons from female mice. These observations suggest that the inhibitory effects of $\mathrm{CNO}$ were attributable, at least in part, to activation of a resting $\mathrm{K}^{+}$conductance. Despite the detection of GIRK channels in DRG, direct evidence that these channels are engaged by endogenous Gi-coupled receptors in the absence of tissue injury is lacking. Although GIRK channel activation could account for the $\mathrm{CNO}$-induced changes in the passive electrophysiological properties (decrease in $R_{\mathrm{in}}$ and hyperpolarization of resting membrane potential) observed in neurons from $V 1^{\text {Gi-DREADD }}$ mice, their biophysical properties argue against this. GIRKs are hyperpolarization-activated channels that close with membrane depolarization (Lüscher and Slesinger, 2010), and they are generally not thought to contribute to AP repolarization. Furthermore, an increase in GIRK conductance associated with membrane hyperpolarization would have resulted in an increased AHP magnitude. Despite detecting GIRK channel mRNA in both control and $V 1^{G i-D R E A D D}$ ganglia, the CNO-induced decrease in excitability was associated with both a decrease in AP duration and AHP magnitude. Therefore, an alternative possibility is that Gi-DREADD is coupled to a LVA K ${ }^{+}$channel (Gold et al., 1996b). A Gi-DREADDmediated leftward shift in the voltage dependence of activation of such a channel would account for the $\mathrm{CNO}$-induced increase in $\mathrm{K}^{+}$ conductance at resting membrane potential; the decrease in AP duration; and, as $\mathrm{LVA} \mathrm{K}^{+}$channels deactivate with membrane hyperpolarization, the decrease in the AHP magnitude. Accordingly, we observed an increase in $\mathrm{LVA} \mathrm{K}^{+}$current in neurons in which $\mathrm{CNO}$ was associated with a decrease in excitability.

Not only was the second-messenger signaling cascade/effector system engaged by Gi-DREADD (i.e., a $\mathrm{K}^{+}$channel) different from that engaged by endogenous $\mathrm{Gi}$-coupled receptors (i.e., VGCC), but the presence of Gi-DREADD appeared to disrupt endogenous second-messenger pathways. For example, given evidence that TTX-R $I_{\mathrm{Na}}$ amplitude is determined by resting kinase activity (Gold et al., 1998), the smaller TTX-R $I_{\mathrm{Na}}$ in $V 1^{\text {Gi-DREADD }}$ neurons is consistent with constitutive activation of Gi signaling. Although the constitutive Gi-DREADD signaling could have created a floor effect precluding the ability to detect the forskolininduced potentiation of TTX-R $I_{\mathrm{Na}}$ in $V 1^{\text {Gi-DREADD }}$ neurons, it is also possible that the absence of forksolin-induced potentiation of TTX-R $I_{\mathrm{Na}}$ in neurons from $V 1^{\text {Gi-DREADD }}$ mice is attributable to the disruption of normal PKA coupling to VGSC. Consistent with this possibility, a higher concentration of forskolin $(30 \mu \mathrm{M})$ failed to produce any detectable increase in TTX-R $I_{\mathrm{Na}}$ in the three neurons tested. Furthermore, the significant reduction in both the DAMGO-induced inhibition of VGCCs and the recovery of DAMGO-induced inhibition with a prepulse to $+80 \mathrm{mV}$ suggested that the presence of Gi-DREADD in these neurons had also disrupted the signaling of endogenous Gi-coupled GPCRs. The loss of DAMGO-induced antinociceptive effects against $\mathrm{PGE}_{2}$-induced hyperalgesia in $V 1^{\mathrm{Gi}-D R E A D D}$ mice is also consistent with a disruption in endogenous $\mathrm{Gi}$ signaling. It is worth noting that the lack of DAMGO effect in female control mice may be caused by a sex difference in $\mu$-opioid potency (Kepler et al., 1991; Craft, 2003; Mitrovic et al., 2003). Finally, the decrease in both VGCCs and VGSCs seems to compensate for the loss of normal inhibitory signaling in these neurons and could account for the relatively normal nociceptive thresholds observed in the absence of CNO.

In retrospect, the changes observed in second-messenger signaling should not have been surprising given the literature on constitutive GPCR signaling, as well as compensatory changes that emerge in response to that signaling (Liu and Prather, 2001; Fioravanti et al., 2008; Murray et al., 2010; Rank et al., 2011; Walwyn et al., 2016). Thus, there was reason to predict that changes in the balance of currents in a sensory neuron would result in changes in NaV1.7 expression. NaV1.7 seemingly plays an important role in the dynamic regulation of nociceptor excitability. Channel density is dramatically increased in the presence of inflammation (Gould et al., 1998) and at least some forms of nerve injury (Liu et al., 2012). More relevantly, there is a compensatory increase in NaV1.7 in DRG from NaV1.8 null mice (Akopian et al., 1999). Interestingly, $\mathrm{NaV1.7}$ also appears to be capable of driving changes, as suggested by recent evidence that a loss-of-function mutation results in a compensatory increase in endogenous opioid expression in DRG neurons (Minett et al., 2015). The extent to which the increase in NaV1.7 contributed to the multiple changes observed in the sensory neurons from $V 1^{\text {Gi-DREADD }}$ mice has yet to be determined. Nevertheless, given the absence of detectable changes in baseline nociceptive threshold or neuronal excitability, the changes observed seem to reflect an attempt to maintain homeostasis in the face of altered Gi signaling. In this regard, the observation that there were quantitative differences in the cellular changes observed in neurons from male and female mice underscores that it is possible to achieve the same phenotype via a variety of different mechanisms. In the context of pain and analgesia, it may not only be possible but necessary to treat men and women differently.

Before the current study, the major concern regarding clinical use of DREADDs was the small but significant proportion of CNO that is metabolized to clozapine (Jann et al., 1994; Chang et al., 1998; Löffleret al., 2012), an antipsychotic that induces glutamate release and unwanted side effects (Meltzer, 2012; Tanahashi et al., 2012; Seeman, 2014; Young et al., 2015). Consequently, new DREADD systems are under construction (Chen et al., 2015; Vardy et al., 2015). However, our results, in addition to findings that indicate differential effects between acute and chronic GiDREADD activation (Soumier and Sibille, 2014), suggest that the agonist may not be the real problem. Therefore, whereas DREADDs may ultimately prove to be an invaluable experimental tool, our results argue that significant additional refinement is required before such an approach is applicable in the clinic. 


\section{References}

Akopian AN, Souslova V, England S, Okuse K, Ogata N, Ure J, Smith A, Kerr BJ, McMahon SB, Boyce S, Hill R, Stanfa LC, Dickenson AH, Wood JN (1999) The tetrodotoxin-resistant sodium channel SNS has a specialized function in pain pathways. Nat Neurosci 2:541-548. CrossRef Medline

Altier C, Zamponi GW (2008) Signaling complexes of voltage-gated calcium channels and G protein-coupled receptors. J Recept Signal Transduct Res 28:71-81. CrossRef Medline

Bourinet E, Altier C, Hildebrand ME, Trang T, Salter MW, Zamponi GW (2014) Calcium-permeable ion channels in pain signaling. Physiol Rev 94:81-140. CrossRef Medline

Cavanaugh DJ, Lee H, Lo L, Shields SD, Zylka MJ, Basbaum AI, Anderson DJ (2009) Distinct subsets of unmyelinated primary sensory fibers mediate behavioral responses to noxious thermal and mechanical stimuli. Proc Natl Acad Sci U S A 106:9075-9080. CrossRef Medline

Cavanaugh DJ, Chesler AT, Braz JM, Shah NM, Julius D, Basbaum AI (2011) Restriction of transient receptor potential vanilloid-1 to the peptidergic subset of primary afferent neurons follows its developmental downregulation in nonpeptidergic neurons. J Neurosci 31:10119-10127. CrossRef Medline

Chang WH, Lin SK, Lane HY, Wei FC, Hu WH, Lam YW, Jann MW (1998) Reversible metabolism of clozapine and clozapine N-oxide in schizophrenic patients. Prog Neuropsychopharmacol Biol Psychiatry 22:723739. CrossRef Medline

Chen X, Choo H, Huang XP, Yang X, Stone O, Roth BL, Jin J (2015) The first structure-activity relationship studies for designer receptors exclusively activated by designer drugs. ACS Chem Neurosci 6:476-484. CrossRef Medline

Craft RM (2003) Sex differences in opioid analgesia: "from mouse to man." Clin J Pain 19:175-186. CrossRef Medline

Dina OA, Hucho T, Yeh J, Malik-Hall M, Reichling DB, Levine JD (2005) Primary afferent second messenger cascades interact with specific integrin subunits in producing inflammatory hyperalgesia. Pain 115:191-203. CrossRef Medline

Ditting T, Linz P, Freisinger W, Heinlein S, Reeh PW, Fiedler C, Siegel K, Scrogin KE, Neuhuber W, Veelken R (2012) Norepinephrine reduces omega-conotoxin-sensitive $\mathrm{Ca} 2+$ currents in renal afferent neurons in rats. Am J Physiol Renal Physiol 302:F350-F357. CrossRef Medline

England S, Bevan S, Docherty RJ (1996) PGE2 modulates the tetrodotoxinresistant sodium current in neonatal rat dorsal root ganglion neurones via the cyclic AMP-protein kinase A cascade. J Physiol 495:429-440. CrossRef Medline

Fioravanti B, De Felice M, Stucky CL, Medler KA, Luo MC, Gardell LR, Ibrahim M, Malan TP Jr, Yamamura HI, Ossipov MH, King T, Lai J, Porreca F, Vanderah TW (2008) Constitutive activity at the cannabinoid CB1 receptor is required for behavioral response to noxious chemical stimulation of TRPV1: antinociceptive actions of CB1 inverse agonists. J Neurosci 28:11593-11602. CrossRef Medline

Fitzgerald EM, Okuse K, Wood JN, Dolphin AC, Moss SJ (1999) cAMPdependent phosphorylation of the tetrodotoxin-resistant voltagedependent sodium channel SNS. J Physiol 516:433-446. CrossRef Medline

Gao XF, Zhang HL, You ZD, Lu CL, He C (2007) G protein-coupled inwardly rectifying potassium channels in dorsal root ganglion neurons. Acta Pharmacol Sin 28:185-190. CrossRef Medline

Gold MS, Reichling DB, Shuster MJ, Levine JD (1996a) Hyperalgesic agents increase a tetrodotoxin-resistant $\mathrm{Na}+$ current in nociceptors. Proc Natl Acad Sci U S A 93:1108-1112. CrossRef Medline

Gold MS, Shuster MJ, Levine JD (1996b) Characterization of six voltagegated $\mathrm{K}+$ currents in adult rat sensory neurons. J Neurophysiol 75:26292646. Medline

Gold MS, Levine JD, Correa AM (1998) Modulation of TTX-R INa by PKC and PKA and their role in PGE2-induced sensitization of rat sensory neurons in vitro. J Neurosci 18:10345-10355. Medline

Goswami SC, Mishra SK, Maric D, Kaszas K, Gonnella GL, Clokie SJ, Kominsky HD, Gross JR, Keller JM, Mannes AJ, Hoon MA, Iadarola MJ (2014) Molecular signatures of mouse TRPV1-lineage neurons revealed by RNASeq transcriptome analysis. J Pain 15:1338-1359. CrossRef Medline

Gould HJ 3rd, England JD, Liu ZP, Levinson SR (1998) Rapid sodium channel augmentation in response to inflammation induced by complete Freund's adjuvant. Brain Res 802:69-74. CrossRef Medline

Heinke B, Gingl E, Sandkühler J (2011) Multiple targets of mu-opioid receptor-mediated presynaptic inhibition at primary afferent Adelta- and C-fibers. J Neurosci 31:1313-1322. CrossRef Medline

Herlitze S, Garcia DE, Mackie K, Hille B, Scheuer T, Catterall WA (1996) Modulation of $\mathrm{Ca} 2+$ channels by G-protein beta gamma subunits. Nature 380:258-262. CrossRef Medline

Ikeda SR (1996) Voltage-dependent modulation of N-type calcium channels by G-protein beta gamma subunits. Nature 380:255-258. CrossRef Medline

Iyer SM, Vesuna S, Ramakrishnan C, Huynh K, Young S, Berndt A, Lee SY, Gorini CJ, Deisseroth K, Delp SL (2016) Optogenetic and chemogenetic strategies for sustained inhibition of pain. Sci Rep 6:30570.

Jann MW, Lam YW, Chang WH (1994) Rapid formation of clozapine in guinea-pigs and man following clozapine-N-oxide administration. Arch Int Pharmacodyn Ther 328:243-250. Medline

Kawano T, Zoga V, McCallum JB, Wu HE, Gemes G, Liang MY, Abram S, Kwok WM, Hogan QH, Sarantopoulos CD (2009) ATP-sensitive potassium currents in rat primary afferent neurons: biophysical, pharmacological properties, and alterations by painful nerve injury. Neuroscience 162 : 431-443. CrossRef Medline

Kepler KL, Standifer KM, Paul D, Kest B, Pasternak GW, Bodnar RJ (1991) Gender effects and central opioid analgesia. Pain 45:87-94. CrossRef Medline

Lee HM, Giguere PM, Roth BL (2014) DREADDs: novel tools for drug discovery and development. Drug Discov Today 19:469-473. CrossRef Medline

Levine JD, Taiwo YO (1989) Involvement of the mu-opiate receptor in peripheral analgesia. Neuroscience 32:571-575. CrossRef Medline

Liu C, Cao J, Ren X, Zang W (2012) Nav1.7 protein and mRNA expression in the dorsal root ganglia of rats with chronic neuropathic pain. Neural Regen Res 7:1540-1544. CrossRef Medline

Liu JG, Prather PL (2001) Chronic exposure to mu-opioid agonists produces constitutive activation of mu-opioid receptors in direct proportion to the efficacy of the agonist used for pretreatment. Mol Pharmacol 60: 53-62. Medline

LöfflerS, KörberJ, Nubbemeyer U, Fehsel K (2012) Comment on "Impaired respiratory and body temperature control upon acute serotonergic neuron inhibition." Science 337:646. CrossRef Medline

LüscherC, Slesinger PA (2010) Emerging roles for G protein-gated inwardly rectifying potassium (GIRK) channels in health and disease. Nat Rev Neurosci 11:301-315. CrossRef Medline

Malin SA, Molliver DC, Koerber HR, Cornuet P, Frye R, Albers KM, Davis BM (2006) Glial cell line-derived neurotrophic factor family members sensitize nociceptors in vitro and produce thermal hyperalgesia in vivo. J Neurosci 26:8588-8599. CrossRef Medline

Malin SA, Davis BM, Molliver DC (2007) Production of dissociated sensory neuron cultures and considerations for their use in studying neuronal function and plasticity. Nat Protoc 2:152-160. CrossRef Medline

Maruyama H, Yamamoto M, Matsutomi T, Zheng T, Nakata Y, Wood JN, Ogata N (2004) Electrophysiological characterization of the tetrodotoxin-resistant $\mathrm{Na}+$ channel, $\mathrm{Na}(\mathrm{v}) 1.9$, in mouse dorsal root ganglion neurons. Pflugers Arch 449:76-87. CrossRef Medline

McCleskey EW (2000) Ion channel selectivity using an electric stew. Biophys J 79:1691-1692. CrossRef Medline

Meltzer HY (2012) Clozapine: balancing safety with superior antipsychotic efficacy. Clin Schizophr Relat Psychoses 6:134-144. CrossRef Medline

Minett MS, Pereira V, Sikandar S, Matsuyama A, Lolignier S, Kanellopoulos AH, Mancini F, Iannetti GD, Bogdanov YD, Santana-Varela S, Millet Q, Baskozos G, MacAllister R, Cox JJ, Zhao J, Wood JN (2015) Endogenous opioids contribute to insensitivity to pain in humans and mice lacking sodium channel Nav1.7. Nat Commun 6:8967. CrossRef Medline

Mishra SK, Hoon MA (2010) Ablation of TrpV1 neurons reveals their selective role in thermal pain sensation. Mol Cell Neurosci 43:157-163. CrossRef Medline

Mishra SK, Tisel SM, Orestes P, Bhangoo SK, Hoon MA (2011) TRPV1lineage neurons are required for thermal sensation. EMBO J 30:582-593. CrossRef Medline

Mitrovic I, Margeta-Mitrovic M, Bader S, Stoffel M, Jan LY, Basbaum AI (2003) Contribution of GIRK2-mediated postsynaptic signaling to opiate and alpha 2-adrenergic analgesia and analgesic sex differences. Proc Natl Acad Sci U S A 100:271-276. CrossRef Medline

Moore RA, Moore OA, Derry S, Peloso PM, Gammaitoni AR, Wang H (2010) Responder analysis for pain relief and numbers needed to treat in 
a meta-analysis of etoricoxib osteoarthritis trials: bridging a gap between clinical trials and clinical practice. Ann Rheum Dis 69:374-379. CrossRef Medline

Murray KC, Nakae A, Stephens MJ, Rank M, D’Amico J, Harvey PJ, Li X, Harris RL, Ballou EW, Anelli R, Heckman CJ, Mashimo T, Vavrek R, Sanelli L, Gorassini MA, Bennett DJ, Fouad K (2010) Recovery of motoneuron and locomotor function after spinal cord injury depends on constitutive activity in 5-HT2C receptors. Nat Med 16:694-700. CrossRef Medline

Nguyen R, Morrissey MD, Mahadevan V, Cajanding JD, Woodin MA, Yeomans JS, Takehara-Nishiuchi K, Kim JC (2014) Parvalbumin and GAD65 interneuron inhibition in the ventral hippocampus induces distinct behavioral deficits relevant to schizophrenia. J Neurosci 34:1494814960. CrossRef Medline

Nockemann D, Rouault M, Labuz D, Hublitz P, McKnelly K, Reis FC, Stein C, Heppenstall PA (2013) The $\mathrm{K}(+)$ channel GIRK2 is both necessary and sufficient for peripheral opioid-mediated analgesia. EMBO Mol Med 5:1263-1277. CrossRef Medline

Ostman JA, Nassar MA, Wood JN, Baker MD (2008) GTP up-regulated persistent $\mathrm{Na}+$ current and enhanced nociceptor excitability require NaV1.9. J Physiol 586:1077-1087. CrossRef Medline

Portenoy RK, Farrar JT, Backonja MM, Cleeland CS, Yang K, Friedman M, Colucci SV, Richards P (2007) Long-term use of controlled-release oxycodone for noncancer pain: results of a 3-year registry study. Clin J Pain 23:287-299. CrossRef Medline

Rank MM, Murray KC, Stephens MJ, D’Amico J, Gorassini MA, Bennett DJ (2011) Adrenergic receptors modulate motoneuron excitability, sensory synaptic transmission and muscle spasms after chronic spinal cord injury. J Neurophysiol 105:410-422. CrossRef Medline

Ray RS, Corcoran AE, Brust RD, Kim JC, Richerson GB, Nattie E, Dymecki SM (2011) Impaired respiratory and body temperature control upon acute serotonergic neuron inhibition. Science 333:637-642. CrossRef Medline

Ruiz-Velasco V, Ikeda SR (2000) Multiple G-protein betagamma combinations produce voltage-dependent inhibition of $\mathrm{N}$-type calcium channels in rat superior cervical ganglion neurons. J Neurosci 20:2183-2191. Medline

Rush AM, Waxman SG (2004) PGE2 increases the tetrodotoxin-resistant Nav1.9 sodium current in mouse DRG neurons via G-proteins. Brain Res 1023:264-271. CrossRef Medline

Sadana R, Dessauer CW (2009) Physiological roles for G protein-regulated adenylyl cyclase isoforms: insights from knockout and overexpression studies. Neuro-Signals 17:5-22. CrossRef Medline

Schmalbruch H (1987) The number of neurons in dorsal root ganglia L4-L6 of the rat. Anat Rec 219:315-322. CrossRef Medline

Seeman P (2014) Clozapine, a fast-off-D2 antipsychotic. ACS Chem Neurosci 5:24-29. CrossRef Medline

Soumier A, Sibille E (2014) Opposing effects of acute versus chronic blockade of frontal cortex somatostatin-positive inhibitory neurons on behavioral emotionality in mice. Neuropsychopharmacology 39:2252-2262. CrossRef Medline

Stein C (1993) Peripheral mechanisms of opioid analgesia. Anesth Analg 76:182-191. Medline
Taiwo YO, Levine JD (1990) Direct cutaneous hyperalgesia induced by adenosine. Neuroscience 38:757-762. CrossRef Medline

Taiwo YO, Levine JD (1991) Further confirmation of the role of adenyl cyclase and of cAMP-dependent protein kinase in primary afferent hyperalgesia. Neuroscience 44:131-135. CrossRef Medline

Tanahashi S, Yamamura S, Nakagawa M, Motomura E, Okada M (2012) Clozapine, but not haloperidol, enhances glial D-serine and L-glutamate release in rat frontal cortex and primary cultured astrocytes. Br J Pharmacol 165:1543-1555. CrossRef Medline

Vanoye CG, Kunic JD, Ehring GR, George AL Jr (2013) Mechanism of sodium channel NaV1.9 potentiation by G-protein signaling. J Gen Physiol 141:193-202. CrossRef Medline

Vardy E, Robinson JE, Li C, Olsen RH, DiBerto JF, Giguere PM, Sassano FM, Huang XP, Zhu H, Urban DJ, White KL, Rittiner JE, Crowley NA, Pleil KE, Mazzone CM, Mosier PD, Song J, Kash TL, Malanga CJ, Krashes MJ, et al. (2015) A new DREADD facilitates the multiplexed chemogenetic interrogation of behavior. Neuron 86:936-946. CrossRef Medline

Walwyn WM, Chen W, Kim H, Minasyan A, Ennes HS, McRoberts JA, MarvizónJC (2016) Sustained suppression of hyperalgesia during latent sensitization by mu-, delta-, and kappa-opioid receptors and alpha2A adrenergic receptors: role of constitutive activity. J Neurosci 36:204-221. CrossRef Medline

Wang T, Jing X, DeBerry JJ, Schwartz ES, Molliver DC, Albers KM, Davis BM (2013) Neurturin overexpression in skin enhances expression of TRPM8 in cutaneous sensory neurons and leads to behavioral sensitivity to cool and menthol. J Neurosci 33:2060-2070. CrossRef Medline

Wang X, Spandidos A, Wang H, Seed B (2012) PrimerBank: a PCR primer database for quantitative gene expression analysis, 2012 update. Nucleic Acids Res 40:D1144-D1149. CrossRef Medline

Wess J, Nakajima K, Jain S (2013) Novel designer receptors to probe GPCR signaling and physiology. Trends Pharmacol Sci 34:385-392. CrossRef Medline

Yang D, Gereau RW 4th (2002) Peripheral group II metabotropic glutamate receptors $(\mathrm{mGluR} 2 / 3)$ regulate prostaglandin E2-mediated sensitization of capsaicin responses and thermal nociception. J Neurosci 22:63886393. Medline

Young SL, Taylor M, Lawrie SM (2015) "First do no harm.” A systematic review of the prevalence and management of antipsychotic adverse effects. J Psychopharmacol 29:353-362. CrossRef Medline

Zhang MM, Wilson MJ, Gajewiak J, Rivier JE, Bulaj G, Olivera BM, Yoshikami D (2013) Pharmacological fractionation of tetrodotoxinsensitive sodium currents in rat dorsal root ganglion neurons by muconotoxins. Br J Pharmacol 169:102-114. CrossRef Medline

Zhang XL, Mok LP, Katz EJ, Gold MS (2010) BKCa currents are enriched in a subpopulation of adult rat cutaneous nociceptive dorsal root ganglion neurons. Eur J Neurosci 31:450-462. CrossRef Medline

Zhang XL, Mok LP, Lee KY, Charbonnet M, Gold MS (2012) Inflammation-induced changes in $\mathrm{BK}(\mathrm{Ca})$ currents in cutaneous dorsal root ganglion neurons from the adult rat. Mol Pain 8:37. CrossRef Medline

Zhu H, Pleil KE, Urban DJ, Moy SS, Kash TL, Roth BL (2014) Chemogenetic inactivation of ventral hippocampal glutamatergic neurons disrupts consolidation of contextual fear memory. Neuropsychopharmacology 39: 1880-1892. CrossRef Medline 